\title{
Endolithic Algae Affect Modern Coral Carbonate Morphology and Chemistry
}

\section{Stefan Krause ${ }^{1 *}$, Volker Liebetrau', Gernot Nehrke 2 , Timo Damm³ ${ }^{3}$, Sebastian Büsse ${ }^{4}$, Thomas Leipe ${ }^{5}$, Angela Vogts ${ }^{5}$, Stanislav N. Gorb ${ }^{4}$ and Anton Eisenhauer ${ }^{1}$}

${ }^{1}$ GEOMAR Helmholtz Centre for Ocean Research Kiel, Kiel, Germany, ${ }^{2}$ Alfred Wegener Institute Helmholtz Centre for Polar and Marine Research, Bremerhaven, Germany, ${ }^{3}$ Section Biomedical Imaging, Department of Diagnostic Radiology and Neuroradiology, University Hospital Schleswig-Holstein, Kiel, Germany, ${ }^{4}$ Functional Morphology and Biomechanics, Zoological Institute, Kiel University, Kiel, Germany, ${ }^{5}$ Leibniz Institute for Baltic Sea Research, Warnemünde, Germany

While burial diagenetic processes of tropical corals are well investigated, current knowledge about factors initiating early diagenesis remains fragmentary. In the present study, we focus on recent Porites microatolls, growing in the intertidal zone. This growth form represents a model organism for elevated sea surface temperatures (SSTs) and provides important but rare archives for changes close to the seawater/atmosphere interface with exceptional precision on sea level reconstruction. As other coral growth forms, microatolls are prone to the colonization by endolithic green algae. In this case, the algae can facilitate earliest diagenetic alteration of the coral skeleton. Algae metabolic activity not only results in secondary coral porosity due to boring activities, but may also initiate reprecipitation of secondary aragonite within coral pore space, a process not exclusively restricted to microatoll settings. In the samples of this initial study, we quantified a mass transfer from primary to secondary aragonite of around $4 \%$ within endolithic green algae bands. Using $\delta^{18} \mathrm{O}, \delta^{13} \mathrm{C}, \mathrm{Sr} / \mathrm{Ca}, \mathrm{U} / \mathrm{Ca}, \mathrm{Mg} / \mathrm{Ca}$, and $\mathrm{Li} / \mathrm{Mg}$ systematics suggests that the secondary aragonite precipitation followed abiotic precipitation principles. According to their individual distribution coefficients, the different isotope and element ratios showed variable sensitivity to the presence of secondary aragonite in bulk samples, with implications for microatoll-based SST reconstructions. The secondary precipitates formed on an organic template, presumably originating from endolithic green algae activity. Based on laboratory experiments with the green algae Ostreobium quekettii, we propose a conceptual model that secondary aragonite formation is potentially accelerated by an active intracellular calcium transport through the algal thallus from the location of dissolution into coral pore spaces. The combined high-resolution imaging and geochemical approach applied in this study shows that endolithic algae can possibly act as a main driver for earliest diagenesis of coral aragonite starting already during a coral's life span.

Keywords: early diagenesis, secondary precipitation, abiogenic aragonite, element ratio, sea surface temperature, endolithic algae 


\section{INTRODUCTION}

Scleractinian corals have been shaping the Earth's surface since the Triassic (Stanley, 2003), forming massive reef ecosystems. Besides their endosymbionts, scleractinian corals host a diverse microbial community (Rosenberg et al., 2007). Recent investigations discovered $>120$ taxonomic units including over 20 genetic lineages (Marcelino and Verbruggen, 2016) present in skeletons of living corals.

Among the endolithic community, siphonal green algae of the genus Ostreobium are the most common ones (Halldal, 1968; Jeffrey, 1968), producing distinctive green bands in the coral skeleton (Halldal, 1968; Highsmith, 1981; Verbruggen and Tribollet, 2011).

Although known for many years (Duerden, 1902) the colonization dynamics, ecophysiology, and activity of endolithic phototrophs as Ostreobium are not entirely deciphered (Ralph et al., 2007). While evidence exists that colonization by the algae occurs mainly as a result of coral mechanical damage or coral section death (Titlyanov et al., 2008), the entry of Ostreobium during early coral ontogeny, within days after larval settlement, has also been documented (Massé et al., 2018).

Euendolithic green algae, which bore into carbonate minerals, have been identified as major agents of biological reef destruction due to their boring activity in living and dead corals as euendolithic organisms (Tribollet, 2008; Grange et al., 2015). Unfortunately, details regarding the boring mechanism carried out by endolithic green algae and the fate of dissolved carbonate components are unconstrained.

Despite this adverse effect, endolithic green algae may also be beneficial for the host during heat stress situations leading to coral bleaching events. Under this condition, these algae are an alternative source of metabolic products required by the host coral (Schlichter et al., 1995; Fine and Loya, 2002), including also nitrogen compounds (Maier et al., 2010). The study of Hartmann et al. (2010) interpreted the formation of green bands as endolithic algal blooms during episodes of environmental heat stress inducing coral bleaching. An increased endolithic algae activity could lead to more pronounced metabolic fractionation of $\mathrm{CO}_{2}$ manifesting as a locally more positive $\delta^{13} \mathrm{C}$ value of the coral carbonate (Pereira et al., 2015), thus recording environmental stress events. The intracrystalline organic matter of endolithic algae as total hydrolyzable amino acid (THAA) carbon (Gupta et al., 2007) is preserved over centuries in coral skeletons (Ingalls et al., 2003), adding to the established approaches used in paleoceanograpic research. These findings illustrate that endolithic algae, in addition to dissolution, can locally alter coral carbonate properties, representing earliest diagenesis.

The range of reported diagenetic alterations occurring during a coral's life span includes variability in skeletal density, skeletal chemistry $\left(\mathrm{Sr} / \mathrm{Ca}, \mathrm{Mg} / \mathrm{Ca}, \mathrm{U} / \mathrm{Ca}, \delta^{18} \mathrm{O}, \delta^{13} \mathrm{C}\right)$, and coral skeletal organic matrix (Enmar et al., 2000; Hendy et al., 2007; Perrin and Smith, 2007), while reasons for the observed heterogeneity are still a matter of debate. Local magnesium increase could be ascribed to the precipitation of brucite $\left[\mathrm{Mg}\left(\mathrm{OH}_{2}\right)\right]$ as a result of increased $\mathrm{pH}$ due to endolithic green algae photosynthesis
(Buster and Holmes, 2006). Also, secondary aragonite (Macintyre and Towe, 1976; Nothdurft and Webb, 2009) and high Mg-calcite (Nothdurft and Webb, 2009; Griffiths et al., 2013) have been reported from recent and fossil coral skeletons. These secondary minerals show deviating element/calcium from the primary coral aragonite (Griffiths et al., 2013). Although a spatial proximity between secondary carbonate minerals and endolithic algae or micro-boreholes has been noted as a petrographic feature, a clear relationship between endolithic algae activity and the presence of secondary carbonate phases has not been clarified to date.

The scleractinian coral genus Porites is commonly present in all tropical reef environments showing different growth forms (Veron, 2000). In addition to the common subtidal massive growth form (Glynn et al., 1994; Lough et al., 1999), microatolls are found in intertidal environments where vertical coral growth is limited by sea level (Dana, 1849; Stoddart and Scoffin, 1979). In addition to constrain past sea level variability (Woodroffe and McLean, 1990; Chappell et al., 1996; Lewis et al., 2008), modern and fossil microatolls have also been used for robust sea surface temperature (SST) reconstruction using $\delta^{18} \mathrm{O}$ and element ratios (McGregor et al., 2013; Roche et al., 2014; Farley et al., 2018), demonstrating a high degree of reproducibility to the common growth form of the same species (McGregor et al., 2013; Wu et al., 2013). As microatolls grow in the intertidal, they are exposed to higher irradiation and thermal stress as corals growing in subtidal conditions (Schoepf et al., 2015). Endolithic algae as Ostreobium can adapt to elevated ambient temperatures and also increase their metabolic activity (Fine et al., 2005). Therefore, microatolls provide the opportunity to study potentially amplified endolithic green algae-driven early diagenetic processes under increased SSTs.

In this paper, we expand on previous studies using recent Porites microatoll samples from a shallow fossil reef top of Zanzibar, Tanzania, with the intention to decipher early coral mineral diagenesis in the vicinity of endolithic green algae activity. Using micro-computed tomography ( $\mu \mathrm{CT}$ ), scanning electron microscopy (SEM), nanoscale secondary ion mass spectrometry (nanoSIMS), fluorescence microscopy, bulk element, and stable isotope analysis, we illustrate mineral heterogeneities between pristine coral sections and secondary aragonite identified in close proximity to endolithic green algae. Based on laboratory experiments with Ostreobium quekettii, we propose a conceptual model for an algal-driven dissolution-reprecipitation mechanism, involving active longdistance calcium transport within the siphonal cells.

\section{MATERIALS AND METHODS}

\section{Coral Samples}

Two recent Porites microatolls with coral tissue remains still identifying the original growth position were collected in late 2012 from the Buyu Beach area of Unguja $\left(6.16583^{\circ} \mathrm{S}\right.$, $\left.39.19916^{\circ} \mathrm{E}\right)$, the southern of the two main islands of Zanzibar (Figure 1). Close to the time point of sampling, the corals grew in close proximity $(<2 \mathrm{~m})$ to each other on top of a Quaternary reefal limestone platform (Arthurton et al., 1999) and 


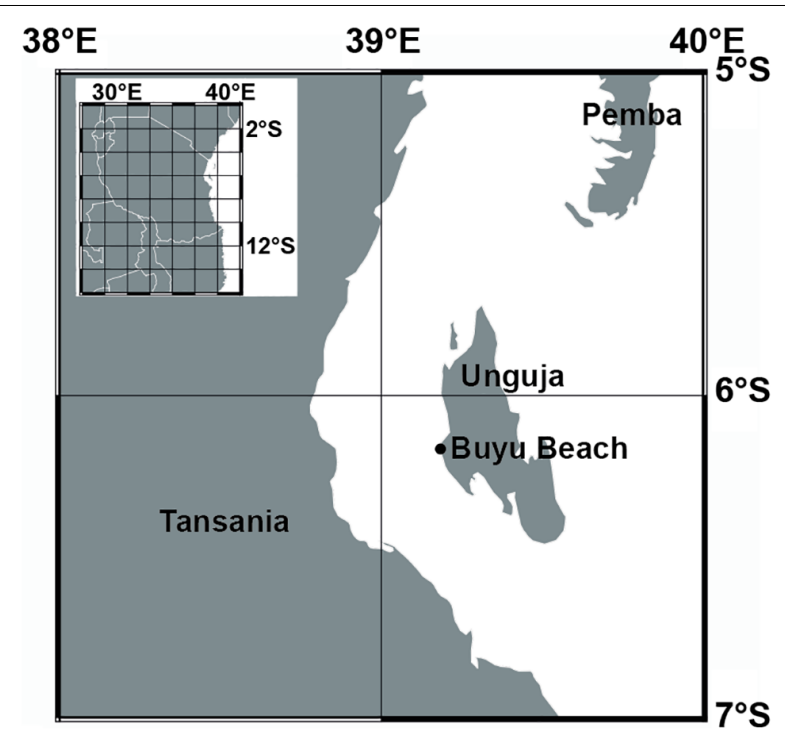

FIGURE 1 | Map showing the sample location of microatolls at the western coast of Unguja island (Zanzibar).

were partly exposed to air when sampled at low tide (Figure 2). Instrumental records of the SST variability, observed for the region between 1982 and 2007, range between 25 and $31^{\circ} \mathrm{C}$ with typical annual variation of $\pm 1^{\circ} \mathrm{C}$ (McClanahan et al., 2007; LaJeunesse et al., 2010).

\section{Sample Preparation}

After retrieval, the microatolls were washed in running freshwater and left to air-dry (Nothdurft and Webb, 2009). After drying, samples showed no signs of surface salt precipitation, indicative for the removal of seawater remains. Subsequently, samples were wrapped in aluminum foil and shipped to the home laboratory. Corals were stored in the dark at approximately $20^{\circ} \mathrm{C}$ until further use. Upon preparation, the corals were free of odor, indicating that extensive decay of organic remnants did not occur during storage time.

The microatolls were cut into several sections using a saw with a blade cooled by running ultra-purified water (resistance 18.2 $\mathrm{M} \Omega \mathrm{cm}^{-1}$ ) to avoid the possibility of thermally induced inversion of aragonite to low-Mg calcite (Waite and Swart, 2015) and redistribution of abraded material. Subsequently, the sections were left to dry at $20^{\circ} \mathrm{C}$.

After optical inspection of the coral pieces, including microscopy and $\mu \mathrm{CT}$ imaging, individual spots for highly selective sub-sampling were defined. Prior to any imaging, coral samples were sonicated for $2 \times 10 \mathrm{~min}$ in ultrapurified water (resistance $18.2 \mathrm{M} \Omega \mathrm{cm}^{-1}$ ) to remove any potentially remaining sawdust from the pore volumes. To prevent unintended dissolution of coral carbonate, the $\mathrm{pH}$ of the water was set to 8.5-9.0 with ammonium solution (25\%, extra pure). After the sonification procedure, samples were rinsed briefly with ultra-purified water and left to dry for $48 \mathrm{~h}$ at $28^{\circ} \mathrm{C}$ in dust-free conditions.
Coral samples for wet chemistry and X-ray diffraction (XRD) analyses were obtained using a handheld power drill with a bediamonded milling cutter. Drilling was carried out at the lowest possible speed to avoid sample warming. Sampling spots were approximately 5-6 $\mathrm{mm}$ in diameter (see Supplementary Figure S2). The obtained discrete powder samples were aliquoted for light stable isotopes $\left(\delta^{18} \mathrm{O}, \delta^{13} \mathrm{C}\right)$, element ratios $(\mathrm{Sr} / \mathrm{Ca}, \mathrm{Mg} / \mathrm{Ca}$, $\mathrm{U} / \mathrm{Ca}, \mathrm{Li} / \mathrm{Mg})$, and XRD analyses.

Light stable isotopes were analyzed with a Thermo Scientific MAT 253 stable isotope ratio mass spectrometer (SIRMS) connected to an automated carbonate preparation device Kiel CARBO IV at GEOMAR. The isotope values were calibrated vs. NBS 19 (National Bureau of Standards) and the GEOMAR in-house standard ("Standard Bremen," Solnhofen limestone). Values are reported in per mil $(\% 0)$ relative to the VPDB (Vienna Peedee Belemnite) scale, accompanied by a typical reproducibility of $\pm 0.05 \%$ for $\delta^{18} \mathrm{O}$ and $\pm 0.07 \%$ for $\delta^{13} \mathrm{C}$ (SD, $n=8$ ) for the calibrated in-house standard measured during this sample set.

Element concentrations and ratios were determined using a quadrupole inductively coupled plasma-mass spectrometer (QICP-MS, Agilent 7500cx). The Coral standard JCp-1 was used as a reference material and measured every fifth sample and in a total of 10 times $(n=10)$. The average JCp- 1 value and standard deviation was $8.81 \pm 0.04 \mathrm{mmol} / \mathrm{mol}$ for $\mathrm{Sr} / \mathrm{Ca}, 4.19 \pm 0.02$ for $\mathrm{Mg} / \mathrm{Ca}, 1.197 \pm 0.026$ for $\mathrm{U} / \mathrm{Ca}$, and $1.62 \pm 0.02$ for $\mathrm{Li} / \mathrm{Mg}$. Based on these analyses and the external precision at the $95 \%$ confidence level $(2 \sigma)$, the average uncertainty is $0.04 \mathrm{mmol} / \mathrm{mol}$ for $\mathrm{Sr} / \mathrm{Ca}, 0.02 \mathrm{mmol} / \mathrm{mol}$ for $\mathrm{Mg} / \mathrm{Ca}, 0.03 \mathrm{mmol} / \mathrm{mol}$ for $\mathrm{U} / \mathrm{Ca}$, and $0.02 \mathrm{mmol} / \mathrm{mol}$ for $\mathrm{Li} / \mathrm{Mg}$. The error values given in the manuscript are the standard deviation of 10 measurements.

Additional coral subsamples for high-resolution mapping were cut out under sawing conditions mentioned above and embedded in resin for further analytical approaches. After formatting the specimen to the appropriate dimensions, plastic rings with an outer diameter of 1 in were used to hold the samples. Subsequently, the samples were embedded in Araldite ${ }^{\circledR} 2020$ resin (Huntsman International LLC) and left for complete polymerization at $50^{\circ} \mathrm{C}$ over $24 \mathrm{~h}$. After being completely cured, the samples were formatted to the desired measures using a microtome saw (Leica SP 1600). The samples were then ground down and polished with a Tegra-Pol-21 system (Struers, Denmark) to minimize sample surface reliefs down to nano-SIMS adequate quality.

\section{Algae Culture}

A culture of O. quekettii (strain 6.99) was purchased from the Culture Collection of Algae at Göttingen University (SAG). The SAG seawater medium SWES was used for algae culturing. The algae were kept in 250-mL glass bottles containing between 50 and $100 \mathrm{~mL}$ of medium at $20^{\circ} \mathrm{C}$ in a laminar flow box exposed to an illuminance of 128-135 lx. The light intensity was measured with a UNITEST ${ }^{\circledR} 93560$ luxmeter, equipped with a silicon photodiode. The lux measurement accuracy is $\pm 2 \%$. All bottles were closed with autoclaved cotton plugs permitting gas exchange between the bottle volume and ambient atmosphere. The SWES medium was exchanged every 14 days. When the algal mass had 


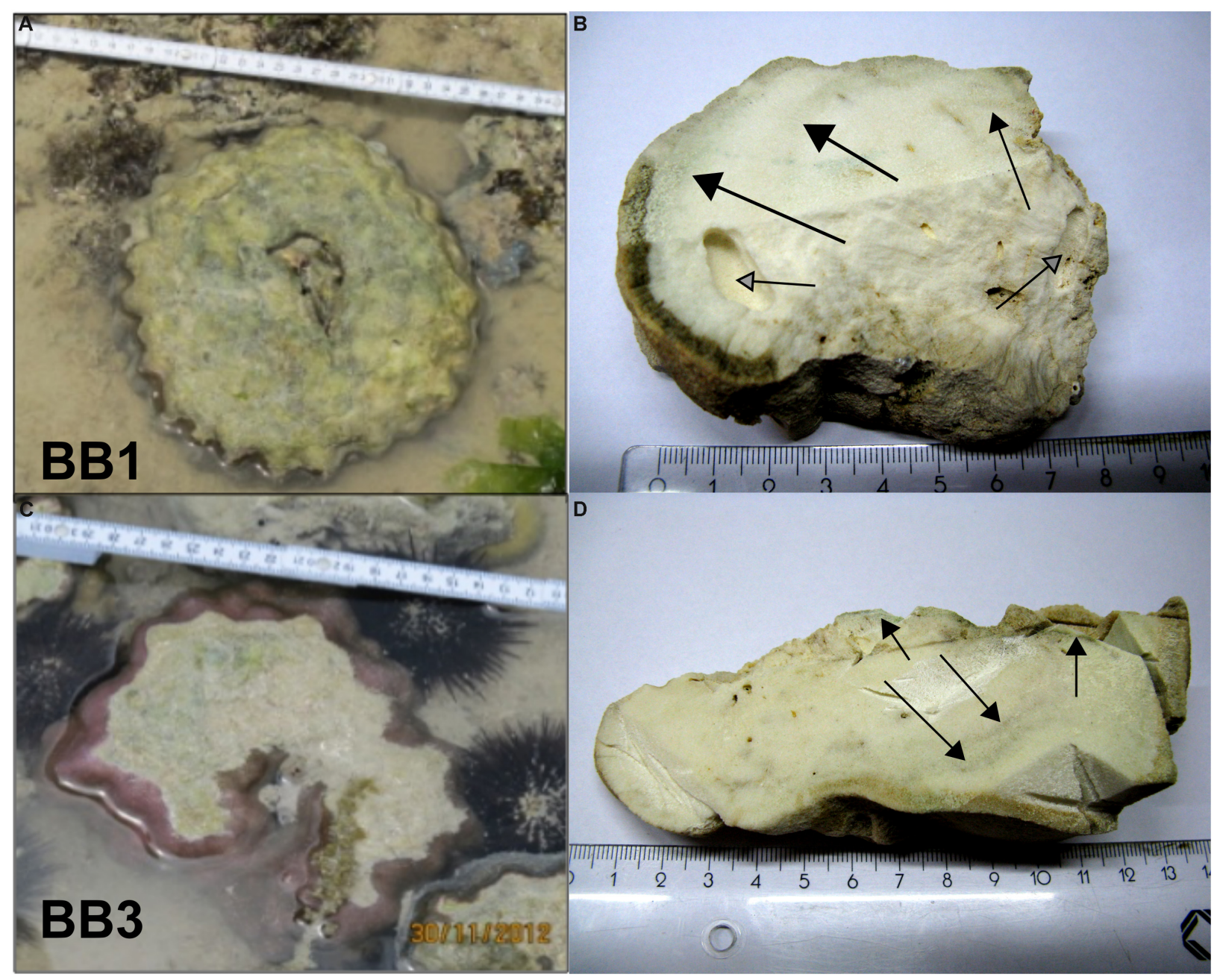

FIGURE 2 | Original positions of the two Porites microatolls on the Buya Beach reef during low tide and corresponding coral slabs used for further analyses. (A,B) BB1. (C,D) BB3. Arrows indicate macroscopically visible green algae bands perpendicular to the coral surfaces.

approximately tripled after 2 months, $100 \mu \mathrm{L}$ of algal volume was inoculated into a new bottle with medium.

\section{Intracellular Calcium Transport}

The variation of calcium concentration in O. quekettii in two different illuminance conditions (high light vs. low light) was investigated under laboratory conditions. Available skeleton parts of the scleractinian coral Stylophora pistillata were used as appropriate hard substrate. The branches were cut into small plates of several centimeters in length and a diameter of approximately $3 \mathrm{~mm}$ using a handheld power drill with a diamond-coated saw blade. Subsequently, the plates were ultrasonicated and dried as described above. In order to remove any organic residue, the plates were bleached in $1 \% \mathrm{NaClO}$ for $48 \mathrm{~h}$, followed by thorough rinsing in ultra-purified water. Finally, the coral plates were dried at $30^{\circ} \mathrm{C}$ under clean room conditions.

For the experiment, $S$. pistillata plates were placed individually in transparent plastic Petri dishes filled with sterile SWES medium. Subsequently, approximately $50 \mathrm{~mL}$ of $O$. quekettii volume was placed directly on top of each plate. In addition, Petri dishes including only SWES medium and O. quekettii were also prepared. Dead controls were prepared using O. quekettii fixed in $4 \%$ formalin for $24 \mathrm{~h}$.

For highlight conditions, Petri dishes with closed lid were placed inside a clean bench exposed to an illuminance of 128$135 \mathrm{~lx}$. Low-light conditions were created in a lightproof box with lid by cutting $1 \times 1 \mathrm{~cm}$ holes at the bottom, which were approximately $12 \mathrm{~cm}$ apart. The box was mounted with a $2-\mathrm{cm}$ clearance to a tabletop. Light penetrating through each hole inside the box had an illuminance of 0.64-0.37 lx. Each sample set for the two light conditions included living and dead $O$. quekettii with and without coral plates. Four replicates were prepared for each treatment. Algae sampling was carried out after 6 and 60 days.

The Fluo- $4^{\mathrm{TM}}$ AM staining kit was used to image intracellular variability of calcium levels of the $O$. quekettii cytosol. For staining, $50 \mu \mathrm{g}$ of desiccated dye was dissolved in $20 \mu \mathrm{L}$ of dimethyl sulfoxide (DMSO) to produce a $2.3 \mathrm{mM}$ stock solution. 
For staining, approximately $50-\mu \mathrm{L}$ algae volume was added to $2295 \mu \mathrm{L}$ of SWES medium and $5 \mu \mathrm{L}$ of Fluo- 4 AM stock solution (final Fluo-4 concentration was $5 \mu \mathrm{M}$ ). Subsequently, the samples were kept in the dark for $30 \mathrm{~min}$. After staining, the algae tissue was placed shortly on Whatman ${ }^{\mathrm{TM}}$ filter paper and placed on a microscopy glass slide and covered with a glass slip. Epifluorescence microscopy imaging was carried out using an enhanced green fluorescent protein (EGFP) filter cube.

\section{Microscopy and SEM}

Coral subsamples and algae cultures were imaged using a Zeiss AxioImager.M2 and a 12-BitAxio Cam MRm Rev.3 camera at GEOMAR. The software package ZEN 2.3 (Blue edition) was used for image acquisition and processing. SEM was carried out using a Zeiss Merlin Compact scanning electron microscope at IOW. For conductivity, samples were sputter-coated with a 10 -nm chromium layer. Images were obtained using secondary electron emission.

\section{X-Ray Diffraction}

For XRD analysis, the obtained powder was ground in an agate mortar and distributed evenly on a silicon disk. Analyses were run from 4 to 75 2-theta (degree) angle at 0.5/min on a Philips X-ray diffractometer PW 1710 with monochromatic Co anode at GEOMAR. The XRD detection limit for aragonite and calcite is 2.9 and $0.9 \mathrm{~mol} \%$, respectively (Kontoyannis and Vagenas, 2000).

\section{Confocal Raman Microscopy}

Confocal Raman microscopy (CRM) is an ideally suited analytical method to determine mineral phases within biogenic materials with high (micrometer range) spatial resolution (e.g., Nehrke and Nouet, 2011). CRM measurements in this study were performed at the AWI by means of a WITec alpha $300 \mathrm{R}$ instrument connected to a diode laser having an excitation wavelength of $488 \mathrm{~nm}$. Raman spectra have been obtained using a Zeiss $20 \times$ Epiplan lens (NA 0.4) and an UHTS300 ultra high-throughput spectrometer (WITec GmbH, Ulm, Germany) equipped with a $1800 \mathrm{~mm}^{-1}$ grating blazed at $500 \mathrm{~nm}$. Raman spectra were measured and analyzed using the WITec ProjectFOUR software. An optical clear calcite single crystal (Iceland-spar from Mexico) and a clear aragonite crystal (from Aragon in Spain) have been used as well-defined (XRD) in-house standards to obtain Raman reference spectra under the same conditions the samples have been measured at.

\section{Electron Microprobe (EMP) Element Mapping}

A JEOL JXA 8200 electron microprobe (EMP) was used at GEOMAR to generate element distribution maps for $\mathrm{Ca}$ and $\mathrm{Sr}$ on cross-sections of the coral skeleton. Each sample was carbon coated before the measurements. Measurements were carried out at an acceleration voltage of $15.0 \mathrm{kV}$, a beam current of $20 \mathrm{nA}$, a beam diameter of $2 \mu \mathrm{m}$, a dwell time of $500 \mathrm{~ms}$, and 10 accumulations for each image. Calibration of $\mathrm{Sr}$ and Ca concentrations was done using four standards with known average concentrations [VG-2 (Jarosewich et al., 1980), KAN-1 (Reay et al., 1993), strontionite (Jarosewich and White, 1987), and calcite (Jarosewich and MacIntyre, 1983)]. Results are illustrated as maps of quantitative element abundance in mass $\%$ and atomic $\mathrm{Sr} / \mathrm{Ca}$. The JEOL JXA 8200 was also used to generate the secondary electron images of the mapped area.

\section{NanoSIMS Element Mapping}

The samples were coated with a 40-nm carbon layer using a Cressington carbon coater 108 carbon/A (Watford, United Kingdom). Areas of interest were selected based on the approximate position based on previous microscopy analyses and the appearance in the NanoSIMS CCD-Camera $(4 \times$ magnification). SIMS imaging was performed using a NanoSIMS 50L instrument (Cameca, Paris, France). The ${ }^{133} \mathrm{Cs}^{+}$primary ion beam was used to erode and ionize atoms of the sample. The electron flood gun was employed for compensation of charging effect in the area of the analysis. Maps of ${ }^{13} \mathrm{C}^{-},{ }^{18} \mathrm{O}^{-},{ }^{32} \mathrm{~S}^{-}$, and ${ }^{12} \mathrm{C}^{14} \mathrm{~N}^{-}$abundances were recorded simultaneously as indicators for organic material within the coral. Less abundant ions $\left({ }^{13} \mathrm{C}^{-}\right.$, ${ }^{18} \mathrm{O}^{-}$) were employed because the signals of the main ions were too high for detection in parallel with the sulfur signal. Prior to the analysis, sample areas of $50 \times 50 \mu \mathrm{m}$ were sputtered for $7 \mathrm{~min}$ with $600 \mathrm{pA}$ to erode the carbon coating, clean the surface, and reach the steady state of secondary ion formation. The primary ion beam current during the analysis was 5-20 pA, depending on the signal intensities. For areas of $25 \times 25 \mu \mathrm{m}, 60$ planes were analyzed.

Different spots with similar optical appearance were analyzed with the NanoSIMS Oxygen source (Duoplasmatron). Different spots were selected to avoid potential bias by the implanted Cs and already eroded surface. The pictures presented for $\mathrm{Sr} / \mathrm{Ca}$ and $\mathrm{Mg} / \mathrm{Ca}$ were derived from location at the surface of the same pore. Measurements in other pores substantiated the findings (data not shown). Prior to the analysis, sample areas of $50 \times 50 \mu \mathrm{m}$ were sputtered for $3 \mathrm{~min}$ with $600 \mathrm{pA}$ to erode the carbon coating, 18to $20-\mu \mathrm{m}$ squares were analyzed, and ${ }^{24} \mathrm{Mg}^{+},{ }^{39} \mathrm{~K}^{+},{ }^{40} \mathrm{Ca}^{+}$, and ${ }^{88} \mathrm{Sr}^{+}$ions were recorded. The primary ion beam current during the analysis was $50 \mathrm{pA}$. Thirty planes were analyzed.

For analyses with both sources, the ions were detected with mass detectors equipped with electron multipliers (Hamamatsu). The scanning parameters were $512 \times 512$ pixels with a dwell time of $250 \mu$ s per pixel. The mass resolving power was adjusted to be sufficient to suppress interferences at all masses allowing, e.g., the separation of ${ }^{32} \mathrm{~S}^{-}$from interfering ions such as ${ }^{16} \mathrm{O}_{2}{ }^{-}$. The instrumental drift was checked by repeated analysis of one sample spot in the course of the measurements. No systematic drift was revealed.

Data analysis was performed with the Look@NanoSIMS software package (Polerecky et al., 2012). The planes were checked for signal instabilities, drift corrected, and accumulated. Ratio images were produced based on the ion count pictures.

It is worth noting that SIMS analyses are a destructive technique. Thus, a volume of the sample is consumed and several layers are eroded. However, the sample erosion by the Cs source was shown to be small enough to resolve cell size features [5.7 $\mathrm{nm} /$ pane for a less intense primary ion beams focused to 
a smaller area (Saka et al., 2014)]. In addition, the planes were inspected carefully for signal changes with depth. Thus, we have no hint that a change of the sample with depth by, e.g., reaching edges of aragonite did occur and altered the results.

\section{Micro-Computed Tomography}

To image two entire coral slabs (Figures 2B,D), a VivaCT 80 (Scanco Medical AG, Brüttisellen, Switzerland) $\mu$ CT scanner, usually used for preclinical in vivo imaging, was used, which permits a scan diameter of $80 \mathrm{~mm}$ with a scan length of up to $150 \mathrm{~mm}$. The used low-noise medium-resolution protocol (70 kVp, $113 \mu \mathrm{A}, 79.9 \mathrm{~mm}$ FOV, 125 proj./180, $500 \mathrm{~ms}$ integration time, $6 \times 6$ sw-binning, standard filtered back projection reconstruction algorithm including beam hardening correction for the density range of interest) sampled to an isotropic voxel size of $156 \mu \mathrm{m}$. The data were exported to calibrated 16-bit grayscale DICOM image stacks for further processing with the AVIZO 9.6 software. For both slabs, appropriate orthogonal slices from a vertical plane were selected and adjusted for optimal contrast and converted to 8-bit grayscale images.

Intensity line profiles, running perpendicular to the coral surfaces, were obtained using the ImageJ 2.0.0 software package. Clearly distinguishable intensity minima were used for consecutive counting of annual coral growth cycles.

Detailed $\mu \mathrm{CT}$ imaging was carried out with a Skyscan 1172 (Bruker, Kontich, Belgium) at CAU. A coral volume of approximately $8 \times 8 \times 30.0 \mathrm{~mm}$ was cut out of the BB3 coral slab using a slow speed saw. Subsequently, the coral piece was sonicated and dried as described in the sample treatment section. For $\mu \mathrm{CT}$-data acquisition, the sample was mounted on a device-specific specimen holder. Scanning was conducted with an acceleration voltage of $100 \mathrm{kV}$ and a current of $100 \mu \mathrm{A}$, and $\mathrm{X}$-ray projections were captured over a full $360^{\circ}$ rotation $\left(0.25^{\circ}\right.$ increments). Voxel edge length was $8.82 \mu \mathrm{m}$.

The obtained $\mu$-CT data sets were reconstructed using the NRecon software package (Bruker, Kontich, Belgium). Segmentation, visualization, and volume calculations were carried out with the AVIZO 9.6 software package (Thermo Scientific).

\section{SST and Sr Partition Coefficient Calculations}

The $\delta^{18} \mathrm{O}$-SST calculations were carried out using the calibration equation by Grumet et al. (2000) for modern Porites from Tanzania:

$$
\operatorname{SST}\left({ }^{\circ} \mathrm{C}\right)=-8.44-7.75 \times \mathrm{O}(\% \mathrm{VPDB}) .
$$

For the Sr/Ca-SST calculations, the equation of Corrège (2006) for Porites was used:

$$
\operatorname{SST}\left({ }^{\circ} \mathrm{C}\right)=16.4745(10.553-\mathrm{Sr} / \mathrm{Ca}(\mathrm{mmol} / \mathrm{mol})) .
$$

The U/Ca-SST was calculated using the calibration equation of Min et al. (1995) for Porites:

$$
\mathrm{SST}=-18.4 \times \mathrm{U} / \mathrm{Ca}(\mu \mathrm{mol} / \mathrm{mol})+45 .
$$

The Porites Mg/Ca-SST was calculated after Wei et al. (2000):

$$
\mathrm{SST}=-14.13+8.846 \times \mathrm{Mg} / \mathrm{Ca}(\mathrm{mmol} / \mathrm{mol}) .
$$

The SST for $\mathrm{Li} / \mathrm{Mg}$ was calculated using the calibration equation of Hathorne et al. (2013) for Porites from the Ogasawara Islands (Japan):

$$
\operatorname{SST}\left({ }^{\circ} \mathrm{C}\right)=20.9205 \times(2.76-\mathrm{Li} / \mathrm{Mg}(\mathrm{mmol} / \mathrm{mol})) .
$$

The Sr partition coefficient for aragonite $\left(\mathrm{D}_{\mathrm{Sr}, \mathrm{a}}\right)$ was calculated according to:

$$
\mathrm{D}_{\mathrm{Sr}, \mathrm{a}}=(\mathrm{Sr} / \mathrm{Ca})_{\text {aragonite }} /(\mathrm{Sr} / \mathrm{Ca})_{\text {seawater }} .
$$

As no adequate data for modern seawater Sr/Ca are available for the Indian Ocean, the combined mean of the Atlantic and Pacific Ocean of $8.539(\mathrm{~mol} / \mathrm{mol})( \pm 0.45 \% \mathrm{SD})$ was used (De Villiers, 1999). As the total range of $\mathrm{Sr} / \mathrm{Ca}$ of both oceans combined is $<1.5 \%$, we consider this value also representative for the Indian Ocean. As a consequence, we assume also an uncertainty of 1.5\% for the calculated $\mathrm{D}_{S r, a}$.

\section{RESULTS}

\section{Coral Age and Morphological Features}

Prepared sections of the Porites microatolls BB1 and BB3 showed macroscopically visible green bands with an approximate thickness between 2 and $5 \mathrm{~mm}$ (Figures 3A,E). The consecutive counting of low-intensity bands from CT-based orthogonal slices from the most inner part to the recent coral surface yielded approximate coral life spans of 12 years for both microatolls (see Supplementary Figure S1). The annual linear extension varied between 0.3 and $0.9 \mathrm{~cm}$ year $^{-1}$ with a mean linear extension of $0.7 \mathrm{~cm}(\mathrm{SD} 0.2 \mathrm{~cm}, n=11) \mathrm{cm} \mathrm{year}^{-1}$ for BB1 and $0.6 \mathrm{~cm}$ (SD $0.2 \mathrm{~cm}, n=11) \mathrm{cm}_{\text {year }}{ }^{-1}$ for BB3.

Based on comparison with previous studies (e.g., Kornmann and Sahling, 1980; Le Campion-Alsumard et al., 1995; Yamazaki et al., 2008), thalli networks, which are characteristic for the green algae genus Ostreobium, were identified in the green bands using light and epifluorescence microscopy (Figure 3). The thalli were siphonal filaments with a diameter of approximately $5 \mu \mathrm{m}$ and a length of several hundred micrometers (Figures 3B,C,F,G). Repeated branching in combination with knobby surface irregularities, typical for Ostreobium, was frequently observed. The prevailing structures could be clearly distinguished from endolithic cyanobacteria as characteristic septa between consecutive vegetative cells were not present. The sole presence of terminal sporangia (Figures $\mathbf{3 C}, \mathbf{F}$ ) also discriminates the observed thalli from cyanobacteria, as the latter produce heterocysts. Although organic deterioration impeded genetic characterization, the combination of distinct morphological features strongly advocates for members of the Ostreobium group. Electron backscatter imaging perpendicular to the coral surfaces revealed strong heterogeneities of skeleton porosity. Areas inhabited by endolithic algae were characterized by numerous boring voids with diameters matching the cell diameter of $O$. quekettii, indicative for metabolically induced 


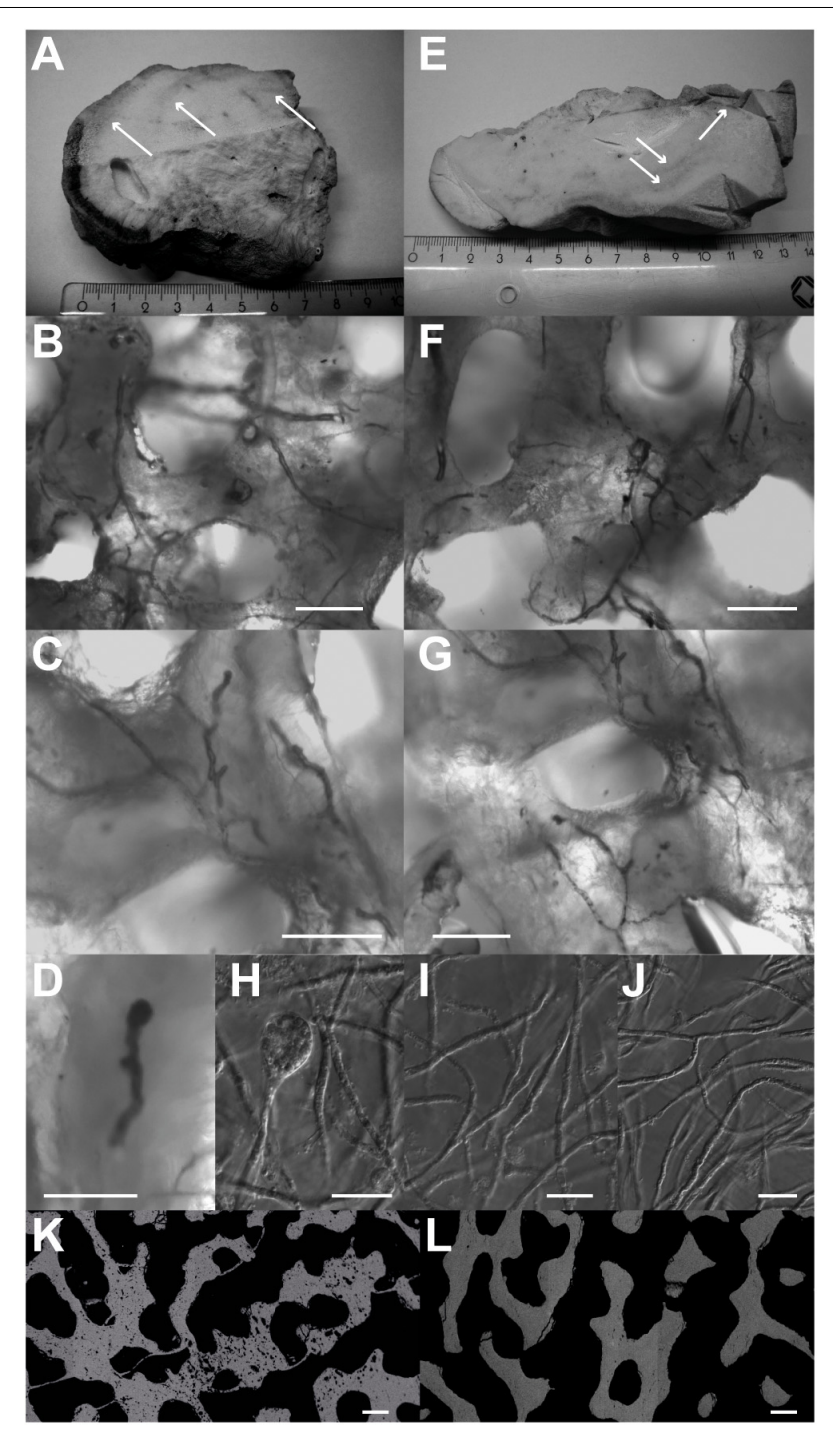

FIGURE 3 | Algae green bands (white arrows) with Ostreobium thalli found in green bands of BB1 (A-D) and BB3 (E-G) and images from cultured O. quekettii $(\mathbf{H}-\mathbf{J})$. Different stages of sporangia development were observed in the coral samples (D - premature algae sporangium from BB1) and in the cultures ( $\mathbf{H}$ - mature algae sporangium). Pure cultures of $O$. quekettii show thalli networks $(\mathbf{I}, \mathbf{J})$ similar to the ones found in coral green bands. Scale bars, $20 \mu \mathrm{m}$. Electron backscatter images of BB3 cross-section show coral skeleton parts inhabited $\mathbf{( K )}$ and devoid $\mathbf{( L )}$ of endolithic algae with different degrees of secondary porosity. Scale bars, $100 \mu \mathrm{m}$.

secondary porosity. For the image in Figure 3K, a total area loss of $4 \%$ due to microporosity was calculated. In contrast, Figure 3L represents a typical region devoid of endolithic algae, characterized by massive coral carbonate.

\section{Visual Diagenesis Indications}

Light as well as SEM revealed the presence of additional algae bands to the ones macroscopically visible. All of these showed increased porosity compared to the skeleton parts without algae bands (Figures $\mathbf{3 K}, \mathbf{L}$ ). At the outermost part of the BB1 section, three concentric bands inhabited by Ostreobium were apparent (Figure 3A). Three consecutive zones also with increased secondary porosity, but without algae remnants, were located in the inner part of the coral. These zones were termed former algae bands (see Supplementary Figure S2). The BB3 section showed five consecutive Ostreobium bands running perpendicular to the coral's growth direction. In addition, another band was situated in close proximity to the coral surface partly overgrown by the younger skeleton section (see Supplementary Figure S2).

Imaging of coral subsamples with SEM confirmed spatial heterogeneity of the pore space surfaces. In the coral surface part, as well as in the algae-free sections, pore space lining appeared as smooth texture (Figure 4A). As this appearance was observed in the youngest and in all algae-free sections, the smooth surface is considered the pristine state.

In contrast, pore space surfaces from algae-band sections showed an area-wide irregular surface consisting of blocky crystals growing on top of the smooth surface. This mineral phase showed strut bundles with blunt or flat apices (Figures $4 \mathrm{~B}, \mathrm{C}$ ) protruding between 5 and $10 \mu \mathrm{m}$ into the pore space volume (Figure 5). These infillings were present also several hundred micrometers away from the cutting edge. In pristine areas, smooth surfaces were present also at the saw-cut edge. Consequently, mineral infilling as a consequence of sawing artifacts can be excluded.

X-ray diffraction small-amount (10-20 mg) bulk measurements as well as high-resolution Raman spectroscopy performed in situ by focusing onto the blocky mineral phase within the pores unambiguously identified the corals as being purely aragonite \{Raman peaks for the two lattice modes (translation mode $\mathrm{T}_{a}, 152 \mathrm{~cm}^{-1}$ and librational mode $\mathrm{L}_{a}, 206 \mathrm{~cm}^{-1}$ ) and the two internal modes [in-plane band $\nu_{4}, \sim 705 \mathrm{~cm}^{-1}$ (double peak) and symmetric stretch $\nu_{1}$, $\left.\left.1085 \mathrm{~cm}^{-1}\right]\right\}$.

\section{Coral Skeleton and Pore Space Volume Variability}

For comparison of the coral/pore space (v\%/v\%) inside and outside of algae bands, a rod-shaped subsample of the BB3 sample (Figure 6) was scanned with $\mu$-CT. The subsample was cut perpendicular to the surface including coral surface material with remains of the polyp tissue followed by three alternating algaefree areas with two intermittent algae bands. The voxel feed size of the used scan was chosen to be $8.82 \mu \mathrm{m}$, thus masking the vast majority of the vermiform Ostreobium burrows, as they were too small in diameter to be resolved. As a result, the algaeinduced secondary porosity did not add to the calculated pore space volume. This advantage was used to constrain volume ratio variabilities between coral skeleton carbonate and primary pore space [coral/pore space (v/v)]. The youngest section of the coral, defined by the presence of coral tissue remnants (Figure 6), and the three algae-free zones showed a coral/pore space relative volume ratio varying between 47:53 and 48:52 (v\%/v\%), which was assumed to represent pristine conditions. In contrast, the two algae bands were distinguished by higher ratios of coral material of 50:50 and 54:46 (v\%/v\%), respectively. 


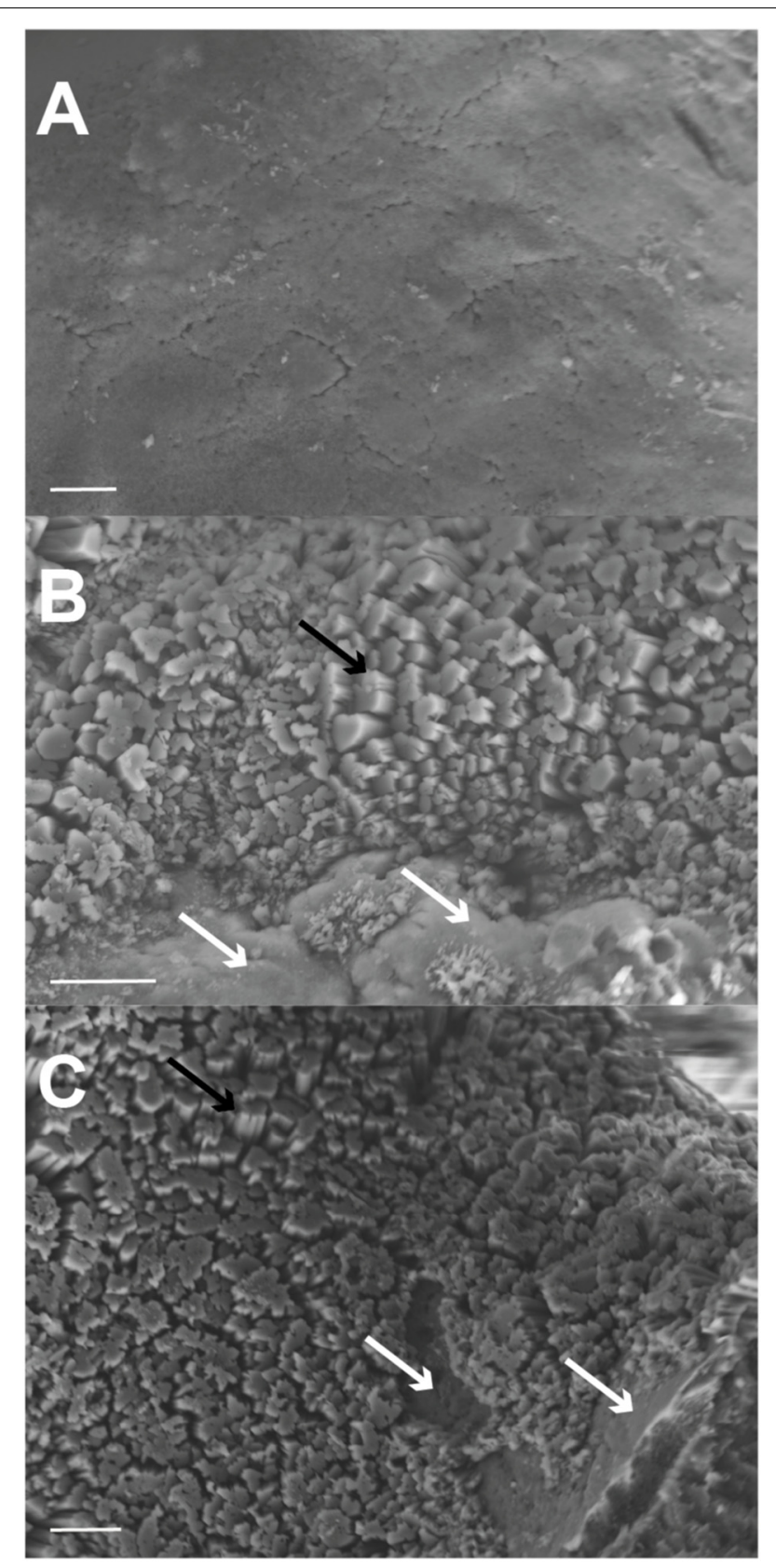

FIGURE 4 | Secondary electron emission (SEM) images of BB3 pore space surfaces. (A) Original surface with smooth texture in algae-free area close to the coral surface. (B,C) Secondary aragonite precipitation (black arrows) widely covering primary coral pore space surfaces (white arrows). Secondary precipitates appear as bundles of short and stumpy struts. Scale bars, $10 \mu \mathrm{m}$.

\section{Spatially Resolved Stable Isotope and Element Ratio Variations}

In total, 13 samples were taken for the combined analysis of $\delta^{18} \mathrm{O}$, $\delta^{13} \mathrm{C}$, and molar Sr/Ca, $\mathrm{U} / \mathrm{Ca}, \mathrm{Mg} / \mathrm{Ca}$, and $\mathrm{Li} / \mathrm{Mg}$ (Table 1) from both corals. Six of the samples were obtained within green algae bands; the remaining were from regions outside of algae bands (for drill sample position, see Supplementary Figure S2).

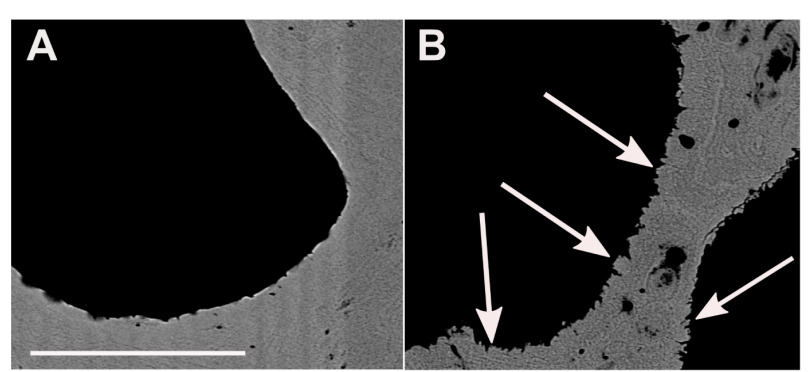

FIGURE 5 | Scanning electron microscopy backscattered electrons image of BB1 cross-sections. (A) Pristine pore space surface. (B) With algae burrows in the coral skeleton and adjacent secondary aragonite precipitates (white arrows). Scale bar for $\mathbf{A}$ and $\mathbf{B}, 100 \mu \mathrm{m}$.

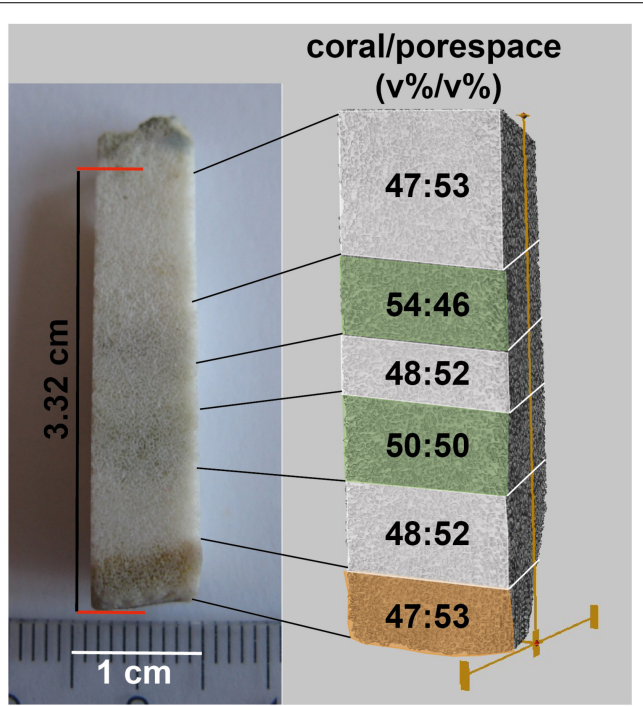

FIGURE 6 | Overview of rod-shaped subsample of BB3 (left) with coral tissue (bottom-orange) and two consecutive algae bands (green). The subsample was $\mu$-CT scanned (right). Subsequently, percent ratios of coral carbonate and pore space were calculated for each of the six indicated volumes.

The mean $\delta^{18} \mathrm{O}$ values within the algae bands were more negative (mean -4.66 , SD $0.35, n=6$ ) than outside (mean -4.55, SD $0.29, n=7)$. The corresponding $\delta^{13} \mathrm{C}$ values showed variability in both groups with amplitudes exceeding $-5 \%$ within algae bands and $-4 \%$ outside, with most negative values found within the algae bands. The mean $\delta^{13} \mathrm{C}$ and $\delta^{18} \mathrm{O}$ values of samples from algae bands showed no significant differences to those obtained outside the bands $\left(\delta^{18} \mathrm{O}, t\right.$ test unpaired, $p$-value $=0.53 ; \delta^{13} \mathrm{C}$, $t$-test unpaired, $p$-value $=0.21)$. The mean $\mathrm{Sr} / \mathrm{Ca}(\mathrm{mmol} / \mathrm{mol})$ was about $2.5 \%$ higher in the bulk samples taken within the algae bands [mean $\mathrm{Sr} / \mathrm{Ca}(\mathrm{mmol} / \mathrm{mol})$ 8.99, SD $0.08(\mathrm{mmol} / \mathrm{mol})$ ], showing a significant difference of the group mean values $(t-$ test unpaired, $p$-value $=0.01$ ). The corresponding $\mathrm{U} / \mathrm{Ca}$ values were also higher in the algae band samples, with overlapping standard deviation. In addition, no significant difference was observed ( $t$-test unpaired, $p$-value $=0.19$ ). The mean $\mathrm{Mg} / \mathrm{Ca}$ was lower in the algae bands $(4.21 \mathrm{mmol} / \mathrm{mol}, \mathrm{SD} 0.4)$ compared to 
TABLE 1 | Bulk sample values for $\delta^{18} \mathrm{O}, \delta^{13} \mathrm{C}, \mathrm{Sr} / \mathrm{Ca}, \mathrm{U} / \mathrm{Ca}, \mathrm{Mg} / \mathrm{Ca}$, and Li/Mg of the microatolls BB1 and BB2.

\begin{tabular}{|c|c|c|c|c|c|c|c|}
\hline \multirow[t]{2}{*}{ Coral } & \multirow[t]{2}{*}{ Location/drill position } & $\delta 13 \mathrm{C}$ & $\delta 180$ & \multirow[t]{2}{*}{$\mathrm{Sr} / \mathrm{Ca} \mathrm{mmol} / \mathrm{mol}$} & \multirow[t]{2}{*}{$\mathrm{U} / \mathrm{Ca} \mu \mathrm{mol} / \mathrm{mol}$} & \multirow[t]{2}{*}{$\mathrm{Mg} / \mathrm{Ca} \mathrm{mmol} / \mathrm{mol}$} & \multirow[t]{2}{*}{$\mathrm{Li} / \mathrm{Mg} \mathrm{mmol} / \mathrm{mol}$} \\
\hline & & (VPDB & (VPDB) & & & & \\
\hline BB1 & Algae band 3 & $-2.24 \pm 0.07$ & $-4.33 \pm 0.05$ & $9.02 \pm 0.09$ & $1.28 \pm 0.01$ & $3.90 \pm 0.01$ & $1.66 \pm 0.02$ \\
\hline BB1 & Algae band 5 & $-0.44 \pm 0.07$ & $-4.82 \pm 0.05$ & $9.11 \pm 0.06$ & $1.31 \pm 0.01$ & $3.76 \pm 0.03$ & $1.69 \pm 0.01$ \\
\hline BB3 & Algae band 9 & $-5.70 \pm 0.07$ & $-4.99 \pm 0.05$ & $8.93 \pm 0.02$ & $1.07 \pm 0.01$ & $4.73 \pm 0.01$ & $1.49 \pm 0.04$ \\
\hline \multicolumn{8}{|l|}{ Mean } \\
\hline Algae band & & -3.11 & -4.66 & 8.99 & 1.18 & 4.21 & 1.56 \\
\hline SD & & 2.07 & 0.35 & 0.07 & 0.11 & 0.40 & 0.09 \\
\hline BB1 & Outside 1 & $-4.81 \pm 0.07$ & $-5.03 \pm 0.05$ & $8.96 \pm 0.08$ & $1.07 \pm 0.01$ & $4.74 \pm 0.01$ & $1.34 \pm 0.01$ \\
\hline BB1 & Outside 4 & $-0.96 \pm 0.07$ & $-4.37 \pm 0.05$ & $8.79 \pm 0.02$ & $1.28 \pm 0.01$ & $4.93 \pm 0.06$ & $1.25 \pm 0.01$ \\
\hline BB3 & Outside 11 & $-1.36 \pm 0.07$ & $-4.19 \pm 0.05$ & $8.81 \pm 0.03$ & $1.08 \pm 0.01$ & $4.45 \pm 0.02$ & $1.48 \pm 0.01$ \\
\hline BB3 & Outside 12 & $-0.75 \pm 0.07$ & $-4.57 \pm 0.05$ & $8.84 \pm 0.05$ & $1.12 \pm 0.01$ & $4.55 \pm 0.01$ & $1.37 \pm 0.01$ \\
\hline \multicolumn{8}{|l|}{ Mean } \\
\hline Outside & & -1.32 & -4.47 & 8.85 & 1.12 & 4.74 & 1.36 \\
\hline \multirow[t]{5}{*}{ SD } & & 0.42 & 0.21 & 0.08 & 0.08 & 0.21 & 0.08 \\
\hline & $t$-test unpaired & & & & & & \\
\hline & $p$-value & 0.21 & 0.53 & $0.01 *$ & 0.19 & $<0.01^{*}$ & $<0.01^{*}$ \\
\hline & Df & 11 & 11 & 11 & 11 & 11 & 11 \\
\hline & $t$-value & -1.34 & -0.65 & 2.91 & 1.41 & -3.14 & 5.01 \\
\hline
\end{tabular}

${ }^{*}$ Denotes significant difference $(p>0.05)$ between group means (algae band vs. outside algae band). Standard deviation (SD) of $\delta 13 C$ and $\delta 180$ individual measurements of were smaller than for the in-house standard. To be conservative the in-house standard SD values for $\delta 13 \mathrm{C}$ and $\delta 180$ are given. Drill positions are reported given in Supplementary Figure S2.

the samples taken outside $(4.74 \mathrm{mmol} / \mathrm{mol}, \mathrm{SD} 0.21)$, showing a highly significant difference $(t$-test unpaired, $p$-value $<0.01)$. Also, the mean $\mathrm{Li} / \mathrm{Mg}$ within the algae band samples was about $14 \%$ higher $(1.58 \mathrm{mmol} / \mathrm{mol})$ compared to the samples outside the bands, showing a significant difference ( $t$-test unpaired, $p$-value $<0.01)$.

\section{High-Resolution Variability}

Nano-SIMS mappings of ${ }^{88} \mathrm{Sr} /{ }^{40} \mathrm{Ca}$ and ${ }^{24} \mathrm{Mg} /{ }^{40} \mathrm{Ca}$ showed that $\mathrm{Sr} / \mathrm{Ca}$ was partially elevated by a factor of approximately two in the blocky aragonite present within algae bands (Figure 7). The corresponding $\mathrm{Mg} / \mathrm{Ca}$ was lower by a factor of two to three. In contrast, $\mathrm{Sr} / \mathrm{Ca}$ showed no increased values at coral pore space surfaces outside algae bands. The $\mathrm{Mg} / \mathrm{Ca}$ was $<$ factor 1 lower at the outermost $2 \mu \mathrm{m}$ of the coral skeleton, compared to the inner part.

A quantitative EMP map (Figure 8, left) showed that the majority of the primary skeleton was characterized by $\mathrm{Sr} / \mathrm{Ca}$ ( $\mathrm{mmol} / \mathrm{mol})$, ranging between 8 and 9; the blocky aragonite could be distinguished by higher ratios between 9 and 10. As the NanoSIMS maps also confirmed higher Sr/Ca, an EMP edge effect can be excluded.

Plotting the distribution coefficient of $\mathrm{Sr}$ in aragonite $\left(\mathrm{D}_{\mathrm{Sr}, \mathrm{a}}\right)$ of the maximum and minimum $\mathrm{Sr} / \mathrm{Ca}$ obtained from the blocky aragonite and the inner coral part against the calculated SST (Corrège, 2006) (Figure 8, right) showed that the $\mathrm{D}_{\mathrm{Sr} \text {, a }}$ values from the blocky aragonite yielded cooler temperatures, outside the instrumental record, while the $\mathrm{D}_{\mathrm{Sr}, \mathrm{a}} / \mathrm{SST}$ relationship obtained for the inner coral skeleton was in agreement.

Calculating the according temperature dependence of the $\mathrm{D}_{\mathrm{Sr}, \mathrm{a}}$ of the blocky aragonite based on inorganic aragonite calibration (Kinsman and Holland, 1969; Dietzel et al., 2004) resulted in a shift back toward warmer temperatures in the range of the instrumental record for SST.

\section{High-Resolution Variabilities of ${ }^{13} \mathrm{C},{ }^{18} \mathrm{O}$, ${ }^{32} \mathrm{~S}$, and ${ }^{12} \mathrm{C}^{14} \mathrm{~N}$}

Using Nano-SIMS, the variabilities in total counts of ${ }^{13} \mathrm{C}$, ${ }^{18} \mathrm{O},{ }^{32} \mathrm{~S}$, and ${ }^{12} \mathrm{C}^{14} \mathrm{~N}$ as indicator for organics were mapped in sub-micron scale by mapping the isotopes across the coral skeleton (Figure 9). Comparing the primary and the secondary precipitates, no obvious differences in isotope concentrations were apparent. However, at the transition area, a fine layer with increased counts of ${ }^{13} \mathrm{C},{ }^{32} \mathrm{~S}$, and ${ }^{12} \mathrm{C}^{14} \mathrm{~N}$ and a simultaneous decrease in ${ }^{18} \mathrm{O}$ counts was detected. This layer matches in position with the less dense layer observed using electron backscatter imaging (Figure 8, left). In contrast, a similar layer is absent at coral surfaces devoid of secondary precipitates. 


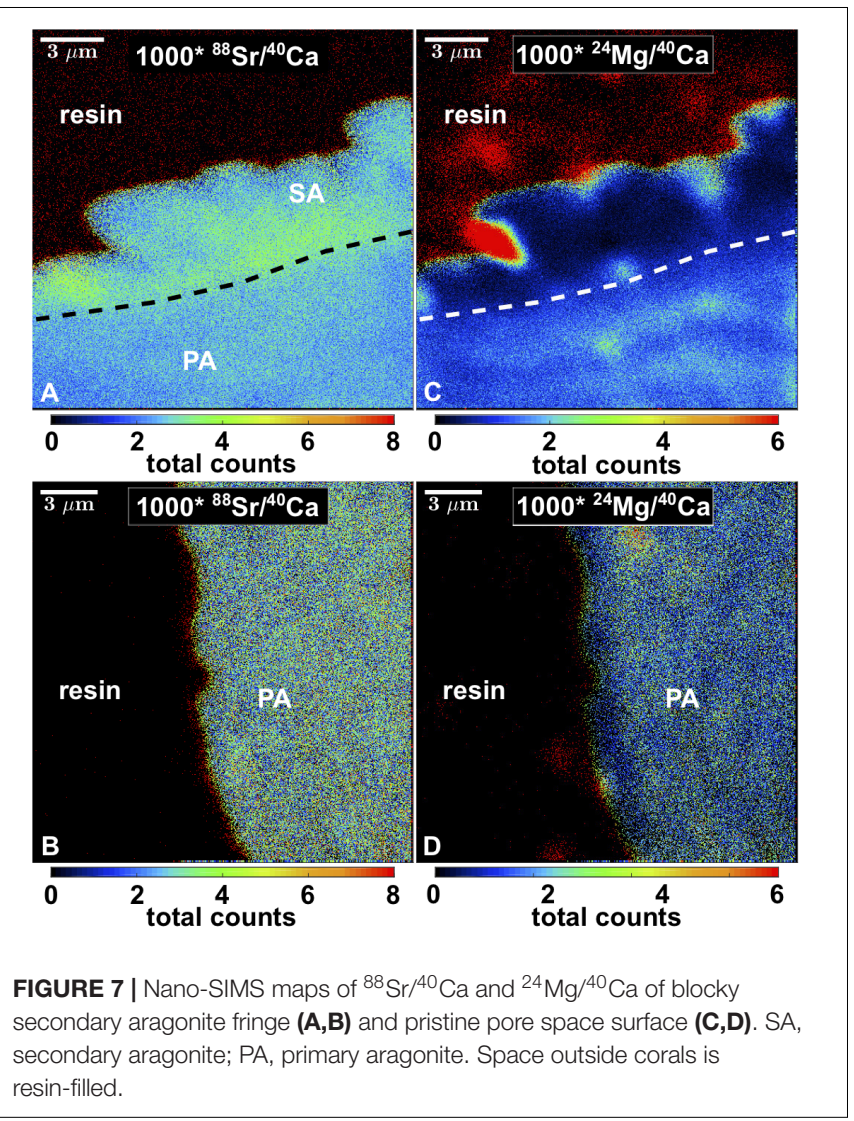

\section{Calcium Transport Within Algae Cells}

In contrast to the impact on SST records of endolithic algae activity, the fundamental mechanisms are less well constrained. To study the fate of elements being dissolved due to the boring activity, we set up an experiment using cultures of $O$. quekettii, belonging to a ubiquitously present group in Porites corals. Living algae were kept under two light intensities (low light, high light) on and without chips of coral skeleton for 60 days in seawater medium. The medium was spiked with Fluo-4 AM, a fluorescent dye suitable to image intracellular concentrations of dissolved calcium.

After 6 days of incubations, the algae incubated on coral chips at low-light conditions showed increased intracellular calcium concentrations at the apical tips of the siphonal thallus (Figure 10A), assuming that calcium uptake was taking place here. In contrast, no increased concentrations were observed in the other three treatments. After 60 days of incubation, markedly increased calcium concentrations were present over several 100 $\mathrm{mm}$ within the algal cells incubated on coral chips (Figure 10E). Assuming prolonged uptake of calcium ions by the apical tips, an intracellular calcium transport over long distances can be hypothesized. A beginning increase of intracellular calcium levels at the apical tips was also observed in algae incubated under highlight conditions on coral chips after 60 days (Figure 10H). The remaining treatments showed no sign of increased intracellular calcium concentrations throughout the entire duration of the experiment (Figures 10B-D,F,G).
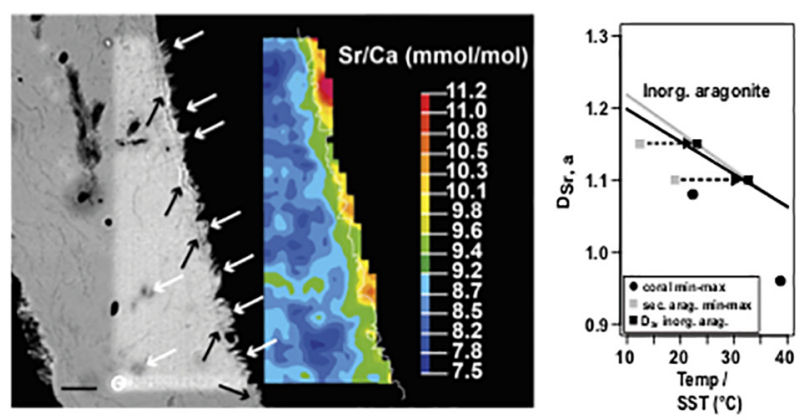

FIGURE 8 | Left: Scanning electron microscopy backscatter image (SEM BSE) and corresponding Sr/Ca mapping of a BB1 microatoll section with secondary aragonite. White arrows denote secondary precipitates on primary skeleton surface and in voids, reflected by green to orange mapping color code. Black arrows show an optical less dense base layer, on which secondary precipitates grow. Fine white line in color map indicates the pixel resolution revised contour between coral (left) and embedding resin (right). Right: Plot of $\mathrm{D}_{\mathrm{Sr}, \mathrm{a}}$ and calculated Sr/Ca-SST for primary coral material (minimum and maximum) and secondary aragonite precipitates (minimum and maximum); applying the vital effect including coral specific calibration of Corrège (2006) suggests unrealistic low formation temperatures for the secondary precipitates, whereas applying an inorganic calibration (Dietzel et al., 2004) on the $D_{S r, a}$ values of the secondary precipitates results in a temperature shift well into the SST range observed for the study area. The black (Dietzel et al., 2004) and gray (Kinsman and Holland, 1969) lines show the systematic offset of temperature-dependent $\mathrm{D}_{\mathrm{Sr}, \mathrm{a}}$ for inorganic aragonite precipitation. Values exceeding a $\mathrm{Sr} / \mathrm{Ca}$ of 10 are attributed to areas of embedding resin. Scale bar, $10 \mu \mathrm{m}$.

\section{DISCUSSION}

\section{Effects of Environmental Factors on Microatoll Morphology and Geochemistry}

Microatolls grow in the intertidal zone, causing coral vertical growth restriction and a dead top due to prolonged emersion during low tides (Scoffin and Stoddart, 1978). As a direct result of emersion, the microatoll top is susceptible to jointly mediated destruction by biological (Perry et al., 2012), chemical (Revelle and Emery, 1957), and mechanical (Jones, 2012) erosion. The consequential increase in coral skeleton porosity at the microatoll top allows for the intrusion of seawater. During emersion periods, increased seawater evaporation can lead to the sequential precipitation of secondary minerals within a microatoll starting with carbonates and followed by gypsum, anhydrite, halite, potassium, and magnesium salts (Berner and Berner, 1987; Boggs, 2014). In the temperature range between 8 and $40^{\circ} \mathrm{C}$, aragonite is likely the dominant carbonate phase (Marion et al., 2009). As highest temperatures occur during the summer months, it can be speculated that abiotic secondary mineral precipitation takes place primarily during this time of year. Consequentially, emersed parts of a microatoll might show variable deviations in bulk geochemistry from nonemersed coral sections.

Microatolls grow under increased heat stress compared to their subtidal counterparts, which can slow down coral growth 

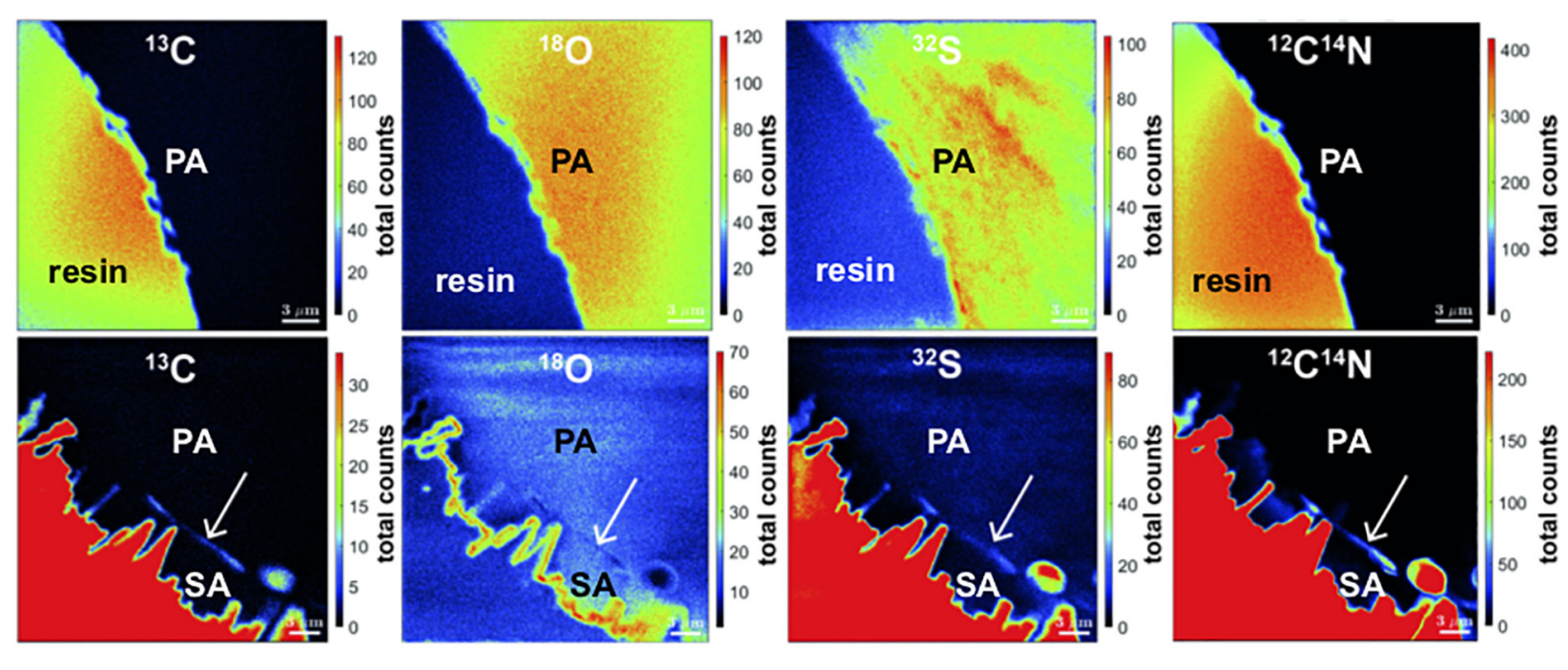

FIGURE 9 | Nano-SIMS mappings of ${ }^{13} \mathrm{C},{ }^{18} \mathrm{O},{ }^{32} \mathrm{~S}$, and ${ }^{12} \mathrm{C}^{14} \mathrm{~N}$ total counts in BB1 coral. Top: pristine pore space without secondary aragonite. Bottom: pore space surface with secondary aragonite precipitates. While the primary coral skeleton is homogeneous in isotope concentrations, the interface between primary and secondary aragonite (white arrows) is characterized by increased total counts of ${ }^{13} \mathrm{C},{ }^{32} \mathrm{~S}$, and ${ }^{12} \mathrm{C}^{14} \mathrm{~N}$, as well as decreased total count concentrations in ${ }^{18} \mathrm{O}$. The epoxy embedding material is characterized by high $\mathrm{C}$ and $\mathrm{S}$ content (red color code).

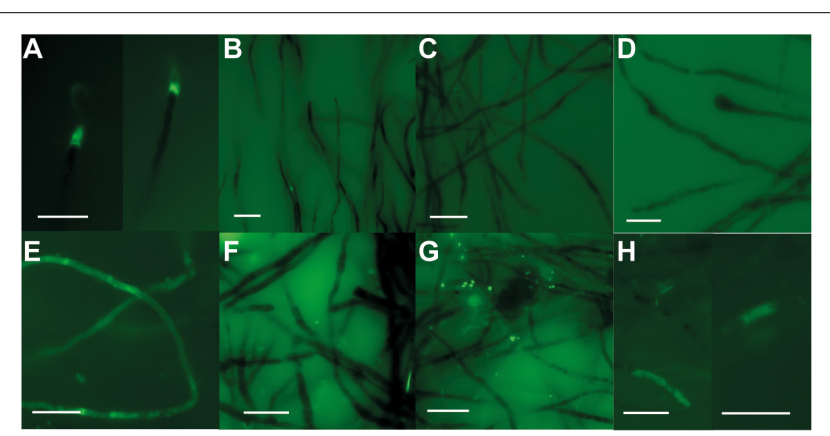

FIGURE 10 | Incubation experiments of O. quekettii with Fluor-4 AM for intracellular Ca imaging after 6 (A-D) and 60 days (E-H). Increased fluorescence indicates increased intracellular Ca levels. (A,E) O. quekettii incubated on coral chip at low-light conditions. Beginning Ca uptake after 6 days $\mathbf{( A )}$ and increased Ca levels within large parts of the siphonal thallus (E). (B,F) Incubation without coral chip at low-light conditions. No apparent increase of intracellular Ca-concentration was detected during the entire incubation period. $(\mathbf{C}, \mathbf{G}) \mathbf{O}$. quekettii incubated without coral chip at high-light conditions. No apparent increase of intracellular Ca-concentration in algal thalli was detected during the entire incubation period. $(\mathbf{D}, \mathbf{H})$ Incubation on coral chip at high-light conditions. After 60 days $\mathbf{( H )}$, beginning Ca uptake was observed. Scale bar, $20 \mu \mathrm{m}$.

(Cantin et al., 2010). Therefore, annual bands might be spaced narrower than in subtidal colonies. Although details regarding a potential change in coral skeleton morphology as a result of heat stress are not constrained, several effects are plausible. During times of highest temperature, a growth hiatus could be initiated, which could occur repeatedly during the annual summer time or erratically during periods of exceptionally high temperatures. Both scenarios would result in a complete loss of climate information during hiatus duration.
Natural skeletal density changes cause the characteristic annual coral banding, with a maximum skeletal density associated with the hottest period of the year (Weber et al., 1975). Compared to subtidal colonies, microatolls are subjected to extended periods of high temperatures. Consequently, their average skeletal density might generally be higher compared to subtidal corals. This, in turn, might increase the microatoll resilience against erosion.

\section{Secondary Aragonite Morphology, Geochemistry, and Mode of Precipitation}

According to Nano-SIMS and EMP measurements, the observed blocky aragonite has a Sr/Ca higher than observed for smooth, pristine pore space surfaces (Figure 7). If the blocky aragonite was the result of coral dissolution, a Sr-Ca exchange must have occurred. This process, however, is highly unlikely as Ca is always preferred to $\mathrm{Sr}$ to be incorporated into the aragonite lattice. Consequently, the observed blocky aragonite is a secondary mineral, precipitated as a result of early diagenesis.

The occurrence of secondary carbonate minerals in tropical corals has been repeatedly reported since the early 1970s for modern, Holocene, and fossil corals (Macintyre and Towe, 1976; Bar-Matthews et al., 1993; Henderson et al., 1993; Obert et al., 2019). The secondary aragonite growing on the smooth pristine pore surfaces of our the studied microatolls are morphologically similar to the blunt aragonite fibers described by RibaudLaurenti et al. (2001) for Holocene Acropora corals and the aragonite laths cement reported for modern and Miocene corals (Griffiths et al., 2013). Living corals harbor a range of secondary carbonates, often in the form of cement (Sayani et al., 2011). The encountered carbonate phases include high-magnesium calcite, low-magnesium calcite (Macintyre and Towe, 1976), as well as aragonite (Hendy et al., 2007). The latter occurs in a variety 
of morphologies ranging from encrusted filaments, botryoids, rods, and needles (Nothdurft and Webb, 2009), and blocky cement (Griffiths et al., 2013). Our study contributes to the suite of diagenetic features in tropical corals, showing that the observed secondary aragonite blocky cement can be the result of earliest diagenesis under marine conditions during a coral's life span, possibly induced by the activity of endolithic green algae. However, the mechanisms inducing alternative aragonite morphologies other than acicular needles are currently not well constrained.

An interesting feature, which, to our knowledge, has not been documented before is a peculiar thin layer of approximately 1- to $2-\mu \mathrm{m}$ thickness marking the transition between the primary coral skeleton and the secondary aragonite overgrowth. This layer appears less dense than the surrounding mineral phases in images of electron backscattering (Figure 8, left). Nano-SIMS mapping of this transition area of primary and secondary aragonite showed that this layer differed by increased counts of ${ }^{13} \mathrm{C},{ }^{32} \mathrm{~S}$, and ${ }^{12} \mathrm{C}^{14} \mathrm{~N}$ and a decreased ${ }^{18} \mathrm{O}$ signal, compared to both aragonite phases (Figure 9). The opposing trend in ${ }^{13} \mathrm{C}$ and ${ }^{18} \mathrm{O}$ counts and the increased counts of the ${ }^{2} \mathrm{C}^{14} \mathrm{~N}$ ion clearly indicate the presence of a thin organic layer (Remusat et al., 2012). Numerous studies have confirmed that the presence of organic templates is directly involved in the microbial nucleation of non-skeletal marine carbonates (Braissant et al., 2003; Degens, 2012; Krause et al., 2012). In contrast, the role of non-coral organic compounds for secondary carbonate precipitation within the coral skeleton is poorly constrained. Endolithic organisms such as $O$. quekettii are known to excrete organic metabolic products potentially beneficial for the coral host tissue (Försterra and Häussermann, 2008). Consequently, it can be assumed that secondary aragonitic cement with morphologies other than acicular needles nucleated under variable influence of present organic compounds within the coral. The individual composition and concentration of organic molecules might then facilitate a variety of crystal morphologies. In the present coral samples, aragonitic overgrowth was observed in the form of blocky cement as documented before (Nothdurft and Webb, 2009). As the secondary aragonite was exclusively observed in green algae bands, it is plausible that the organic compounds, potentially involved in secondary aragonite nucleation, were excreted by the adjacent algae thalli (Duerden, 1902; Fine and Loya, 2002). Nonetheless, other sources of organic compounds, including coral polyp-derived skeletal organic matrix (Abelson, 1955), adsorbed organics from ambient seawater (Isdale, 1984), and organic matter from bacteria (DiSalvo, 1969) or fungi (Bak and Laane, 1987) cannot be excluded completely.

Bulk and spatial high-resolution analyses showed that the secondary aragonite showed increased $\mathrm{Sr} / \mathrm{Ca}, \mathrm{U} / \mathrm{Ca}$, and $\mathrm{Li} / \mathrm{Mg}$, while depleted in $\mathrm{Mg} / \mathrm{Ca}$. This result supports the results of previous studies for secondary aragonite (Enmar et al., 2000; Quinn and Taylor, 2006; Griffiths et al., 2013). As the strontium partition coefficient for the secondary aragonite $\left(\mathrm{D}_{\mathrm{Sr}, \mathrm{a}}\right)$ fitted exactly on the $\mathrm{D}_{\mathrm{Sr}} /$ temperature correlation for inorganic aragonite (Kinsman and Holland, 1969; Dietzel et al., 2004), we can safely assume that the secondary aragonite largely followed inorganic precipitation mechanisms, which is explanatory for the observed difference in element ratios between the primary coral and the secondary aragonite.

Although not statistically significantly different ( $t$-test unpaired, $p$-value $=0.21$, numerous carbonate bulk samples within algae bands showed more negative $\delta^{13} \mathrm{C}$ values than those outside the bands. As green algae have a $\delta^{13} \mathrm{C}$ range between $-20.3 \%$ (VPDB) and -8.8\% (VPDB) (Maberly et al., 1992), it can be speculated that organic algal compounds might have been incorporated into the secondary aragonite.

However, current opinions about secondary carbonate precipitation in corals include precipitation from diffusing seawater as a consequence of microbial redox reactions (Tribble et al., 1990), the presence of intra-coral microenvironments chemically differing from seawater (Nothdurft and Webb, 2009), or a catalytic function of extracellular carbonic anhydrase (CA) activity (Chen et al., 2018). Microbial redox reactions leading to $\mathrm{pH}$ increase and/or alkalinity production (sulfate reduction and denitrification) favoring carbonate precipitation require hypoxic or anoxic conditions (Jørgensen, 1977; Zumft, 1997). These requirements are not met in endolithic algae bands as oxygen concentrations show considerable diurnal fluctuations, reaching hyperoxia during light time (Shashar and Stambler, 1992). Also, the absence of any iron-sulfide minerals supports the assumption of prolonged oxic conditions during secondary aragonite precipitation.

The chemical environment within algae bands is currently not well characterized, and presumably the precipitation of secondary aragonite is governed by more than one factor. Due to the combined boring and photosynthetic activity of the green algae, we can assume that $\mathrm{pH}$ in the algae bands shows heterogeneity, potentially promoting secondary aragonite precipitation in regions with elevated $\mathrm{pH}$. Also, evidence exists that the enzyme CA is present within endolithic photosynthetic algae (Shashar and Stambler, 1992). Within coral skeletons, $\mathrm{CO}_{2}$ concentrations are generally lower than in the ambient seawater (Shashar and Stambler, 1992). In order to counteract $\mathrm{CO}_{2}$ limitation for endolithic photosynthesis, CA converts bicarbonate to $\mathrm{CO}_{2}$, according to the following reaction:

$$
\mathrm{HCO}_{3}^{-}+\mathrm{H}^{+} \leftrightarrow \mathrm{CO}_{2}+\mathrm{H}_{2} \mathrm{O}
$$

Consequently, in case of the reaction driven to the right, the $\mathrm{H}^{+}$removal increases $\mathrm{pH}$, which favors carbonate precipitation. Whether extracellular CA is also involved in liquid-phase $\mathrm{pH}$ modulation is currently unknown.

Another factor to be considered for secondary aragonite precipitation is seasonality. The stoichiometric solubility product $\left(K_{\mathrm{SP}}^{*}\right)$ for aragonite is principally dependent on temperature (Zeebe and Wolf-Gladrow, 2001), resulting in a negative correlation between mineral solubility and temperature. As a consequence, secondary aragonite precipitation could be facilitated during periods of annual peak temperatures. Although the obtained $\mathrm{Sr} / \mathrm{Ca}$ values for the abiotic secondary aragonite of the present study do not indicate intensified precipitation at notably hot temperatures, further studies focused on 
seasonal resolution are required to elucidate the role of annual temperature fluctuations for microatoll secondary aragonite.

\section{Influence of Endolithic Green Algae on Coral Skeleton}

We showed that hot spots of diagenesis were clearly associated with skeleton regions colonized by endolithic green algae resulting in skeleton dissolution and potentially also the precipitation of secondary blocky aragonite within pore spaces of algae bands. The observed skeleton dissolution is in accordance with previous studies identifying endolithic green algae as important agents for coral skeleton erosion (Chazottes et al., 1995; Tribollet and Golubic, 2011). Each of the microatolls showed individual macroscopically visible boreholes of 2-3 mm in diameter, presumably caused by macroborers. Numerous studies also confirmed the important role of macroborers for coral erosion, including lithophagine bivalves (Wizemann et al., 2018) and polychaetes (Davies and Hutchings, 1983). While faunal organisms generally contribute substantially to coral erosion (Zubia and Peyrot-Clausade, 2001; Tribollet and Golubic, 2011), they might be less abundant in microatolls as a consequence of increased heat stress (Przeslawski et al., 2008) at the water surface. Therefore, temperature-tolerant endolithic algae (Fine et al., 2005) might be largely responsible for the observed microatoll internal erosion. From the analysis of twodimensional coral cross-section images, we can infer that around $4 \%$ of the internal skeleton area within an algae band was lost as a direct consequence of boring activity (Figure 3K).

The volumetric calculations suggested a volume gain of 3 and $7 \%$, respectively, within the algae bands. Although it is generally not approved to compare two- and three-dimensional data, it appears plausible that the values obtained for internal coral skeleton dissolution and the coral/pore volume percent ratio reside in the same order of magnitude. This in turn leads to the conclusion that the majority of the dissolved primary coral skeleton could have reprecipitated within a short spatial distance inside the same algae band. Nonetheless, natural variability of coral skeleton to pore space ratio (density) is known for almost five decades (Knutson et al., 1972). In addition to annual, fine monthly and irregular bands are also produced (Barnes and Lough, 1993). Consequently, one can argue that a diagenetic density change is indistinguishable from natural coral density banding. Conventionally, variations in coral skeletal density are routinely analyzed by two-dimensional X-ray radiographs of prepared coral slices (Buddemeier et al., 1974). In order to derive coral density from X-ray density, elaborate calibration algorithms have to be applied involving defined standard material (Chalker et al., 1985). However, a precise quantification of coral skeleton to pore space ratio is virtually impossible. The used $\mu$-CT approach has the advantage of providing such data in a non-destructive way, irrespective of individual sample mineralogy and thickness. Our $\mu$-CT approach demonstrates an increased coral/pore space in both areas inhabited by endolithic algae; whether this is entirely caused by secondary aragonite precipitation, natural coral density variability, or a mixture of both is beyond the scope of this study. However, Ribaud-Laurenti et al. (2001) also found the presence of secondary aragonite to be responsible for pore space volume reduction of up to $50 \%$ in fossil Acropora corals.

The incubation experiments carried out during this study showed uptake of dissolved calcium by the algae $O$. quekettii from the apical tips and subsequent increased calcium levels throughout the siphonal thallus. This observation points to an active uptake of calcium by the algae and subsequent transport toward the distal part of the siphonal thallus. This mechanism prevents increasing calcium concentrations in the borehole, which might lead to spontaneous reprecipitation of carbonate and bore hole clogging.

Active calcium removal from the site of carbonate excavation has so far, to our knowledge, only been observed for cyanobacteria (Garcia-Pichel et al., 2010), but not for green algae.

In our experiments, the intensity of calcium uptake was negatively correlated with light intensity. We can therefore conclude that low-light conditions act as a trigger, initiating boring activity to avoid light limitation. In contrast, calcium incorporation was considerably less intense under high-light conditions. Consequently, it can be assumed that excessive calcium uptake is an energy-demanding process only carried out when necessary. Currently, the exact boring mechanism of endolithic green algae and the fate of the dissolved inorganic carbonate species are unknown. The mechanism could involve an acid-generating metabolism as the boring tip of the thallus or the uptake of calcium ions from the liquid phase at the boring locality to decrease the local carbonate saturation state to an extent to induce spontaneous dissolution (Garcia-Pichel et al., 2010).

As calcium concentrations are usually strictly controlled in all types of organisms (White and Broadley, 2003; Dominguez, 2004; Brini et al., 2013) due to its toxic effects (Smith, 1995), passive diffusion of $\mathrm{Ca}^{2+}$ ions within the algal thallus is highly unlikely. Instead, once taken up, the majority of calcium ions might have been attached to calcium-binding proteins acting as concentration buffers (La Verde et al., 2018). In contrast, calcium transport within cyanobacteria filaments is supposedly mediated by transmembrane calcium pumps (Garcia-Pichel et al., 2010). Once inactivated, the calcium can be transported intracellularly over long distances without adverse physiological effects. Although not observed directly, from the analysis of the coral slabs, we can infer an eventual release of calcium ions into the coral primary pore space volume, inducing secondary precipitation in case of carbonate supersaturation.

\section{Geochemical Implications}

Under the environmental conditions microatolls grow in, including higher temperature and solar radiation, compared to the subtidal environment, endolithic green algae might be an important driver for earliest coral skeleton diagenesis. The obtained results are not straightforward transferrable to other Porites morphotypes, as dome-shaped colonies, growing in several meters of water depth. Due to light attenuation with water depth, endolithic algae colonizing subtidal corals are subjected to less solar energy per area, limiting the photosynthetic activity. Although light limitation is partly compensated by an increased ratio of Chlorophyll $b$ to Chlorophyll $a$ (Schlichter et al., 1997), endolithic green algae generally grow slower under reduced solar 
radiation (Verbruggen and Tribollet, 2011). Consequently, under current conditions observed, algae-facilitated coral dissolution and secondary carbonate precipitation are highly likely to be less prominent in corals growing in subtidal environments.

A reason for focusing on coral microatolls is that they might serve as a model for endolithic algae activity in future climate scenarios, including ocean warming and acidification. Both factors are known to exert environmental stress on corals (Hoegh-Guldberg, 1999; Anthony et al., 2008). As these parameters involve simultaneous heat and $\mathrm{CO}_{2}$ flux across the atmosphere-sea surface boundary, microatolls are currently exposed to an increased heat and $\mathrm{CO}_{2}$ load, which are likely to extend deeper into the ocean in the near future. In fact, ocean acidification has been shown to aggravate biogenic carbonate dissolution by endolithic green algae as Ostreobium sp. stimulated by increased levels of $\mathrm{pCO}_{2}$ (Tribollet et al., 2009).

The present study indicates that endolithic green algaemediated secondary, abiotic aragonite precipitation can have a noticeable influence on the robustness of microatoll SST proxies, generally shifting derived temperatures toward lower values (Table 2). For element ratios, this phenomenon is caused by the differing partition coefficients between the biogenic original and abiotic secondary aragonite. A comparison shows the variable impact of the secondary aragonite on the reliability of the individual proxy approaches.

For the $\delta^{18} \mathrm{O}-\mathrm{SST}$, no principle difference between locations inside and outside the algae bands was observed. Assuming a mass change $\leq 4 \%$ between primary and secondary aragonite, the precipitated amount was too small detect significant $\delta^{18} \mathrm{O}$ overprinting.

The $\delta^{18} \mathrm{O}$ fluctuation throughout the coral is presumably caused by the natural variability (Grottoli, 1999) rather than diagenesis. The $\delta^{18} \mathrm{O}-\mathrm{SST}$ approach generally yielded temperatures between 24 and $32^{\circ} \mathrm{C}$, which agree with the instrumental record, and thus can be regarded as a robust SST approach for microatolls.

Among the trace element proxies, $\mathrm{Sr} / \mathrm{Ca}$ proved to be the most robust one as obtained SST values were generally in good agreement with the $\delta^{18} \mathrm{O}$ data and the instrumental records. Based on $\mu$-CT, microscopy, and Nano-SIMS analyses, the secondary aragonite fringe has a thickness between 5 and $10 \mu \mathrm{m}$. The high-resolution mapping illustrated that the secondary aragonite was characterized by increased $\mathrm{Sr} / \mathrm{Ca}$ (Figures 7, 8), resulting in unreliably low SSTs when calculated using the coral proxy calibration equation. Although significantly different $(t$ test unpaired, $p$-value $<0.01$ ), the mean $\mathrm{Sr} / \mathrm{Ca}$ within and outside the algae bands differed by $<1^{\circ} \mathrm{C}$. According to our approach to constrain a mass balance, we can infer that the contribution of secondary aragonite to the total carbonate is at best between 3 and $7 \%$, which is too low to have a measureable influence on the $\mathrm{Sr} / \mathrm{Ca}$ SST proxy derived from the bulk samples of the current study.

The U/Ca of the bulk samples inside and outside the algae bands showed similar average values. Therefore, the secondary aragonite did not influence this proxy approach to a measureable degree. Considering abiogenic aragonite, it has been shown that $\mathrm{U} / \mathrm{Ca}$ is independent of temperature and $\mathrm{pH}$ in the range of

TABLE 2 | Sea surface temperature values derived from bulk samples $\delta^{18} \mathrm{O}, \mathrm{Sr} / \mathrm{Ca}, \mathrm{U} / \mathrm{Ca}, \mathrm{Mg} / \mathrm{Ca}$, and Li/Mg of the microatolls BB1 and BB2.

\begin{tabular}{|c|c|c|c|c|c|c|}
\hline \multirow[t]{2}{*}{ Coral } & \multirow[t]{2}{*}{ Location/drill position } & $\delta 180$ & $\mathrm{Sr} / \mathrm{Ca}$ & $\mathrm{U} / \mathrm{Ca}$ & $\mathrm{Mg} / \mathrm{Ca}$ & $\mathrm{Li} / \mathrm{Mg}$ \\
\hline & & SST $\left({ }^{\circ} \mathbf{C}\right)^{a}$ & SST $\left({ }^{\circ} \mathbf{C}\right)^{b}$ & SST $\left({ }^{\circ} \mathbf{C}\right)^{\mathrm{c}}$ & SST $\left({ }^{\circ} \mathbf{C}\right)^{d}$ & SST $\left({ }^{\circ} \mathrm{C}\right)^{\mathrm{e}}$ \\
\hline BB1 & Algae band 2 & $27.5 \pm 0.3$ & $26.2 \pm 0.1$ & $23.5 \pm 0.2$ & $22.1 \pm 0.1$ & $25.1 \pm 0.5$ \\
\hline BB1 & Algae band 3 & $25.1 \pm 0.3$ & $25.3 \pm 0.3$ & $21.4 \pm 0.2$ & $20.4 \pm 0.1$ & $23.0 \pm 0.3$ \\
\hline BB1 & Algae band 5 & $28.9 \pm 0.3$ & $23.8 \pm 0.3$ & $20.9 \pm 0.2$ & $19.1 \pm 0.2$ & $22.4 \pm 0.1$ \\
\hline BB3 & Algae band 9 & $30.2 \pm 0.3$ & $26.7 \pm 0.1$ & $25.3 \pm 0.2$ & $27.7 \pm 0.1$ & $26.6 \pm 0.7$ \\
\hline BB3 & Algae band 10 & $30.5 \pm 0.3$ & $26.9 \pm 0.1$ & $25.7 \pm 0.2$ & $27.0 \pm 0.1$ & $27.0 \pm 0.3$ \\
\hline BB3 & Algae band 13 & $24.0 \pm 0.3$ & $25.4 \pm 0.1$ & $22.6 \pm 0.2$ & $22.4 \pm 0.1$ & $26.4 \pm 0.3$ \\
\hline \multicolumn{7}{|l|}{ Mean } \\
\hline Algae band & & 27.7 & 25.7 & 23.2 & 23.1 & 25.1 \\
\hline SD & & 2.7 & 1.2 & 2.0 & 3.5 & 2.0 \\
\hline BB1 & Outside 1 & $30.5 \pm 0.3$ & $26.2 \pm 0.2$ & $25.3 \pm 0.2$ & $27.8 \pm 0.1$ & $29.7 \pm 0.2$ \\
\hline BB1 & Outside 4 & $25.4 \pm 0.3$ & $29.0 \pm 0.1$ & $21.4 \pm 0.2$ & $29.5 \pm 0.4$ & $31.6 \pm 0.2$ \\
\hline BB3 & Outside 6 & $28.8 \pm 0.3$ & $27.4 \pm 0.1$ & $25.3 \pm 0.2$ & $29.8 \pm 0.4$ & $29.9 \pm 0.6$ \\
\hline BB3 & Outside 7 & $25.6 \pm 0.3$ & $25.7 \pm 0.1$ & $24.9 \pm 0.5$ & $28.7 \pm 0.1$ & $28.7 \pm 0.4$ \\
\hline BB3 & Outside 8 & $26.3 \pm 0.3$ & $29.0 \pm 0.2$ & $25.3 \pm 0.2$ & $27.4 \pm 0.1$ & $29.5 \pm 0.8$ \\
\hline BB3 & Outside 11 & $24.0 \pm 0.3$ & $28.7 \pm 0.1$ & $25.1 \pm 0.2$ & $25.2 \pm 0.1$ & $26.8 \pm 0.2$ \\
\hline BB3 & Outside 12 & $27.0 \pm 0.3$ & $28.2 \pm 0.2$ & $24.4 \pm 0.2$ & $26.1 \pm 0.1$ & $29.1 \pm 0.2$ \\
\hline \multicolumn{7}{|l|}{ Mean } \\
\hline Outside & & 26.8 & 27.8 & 24.5 & 27.8 & 29.3 \\
\hline SD & & 2.2 & 1.3 & 1.4 & 1.7 & 1.5 \\
\hline
\end{tabular}

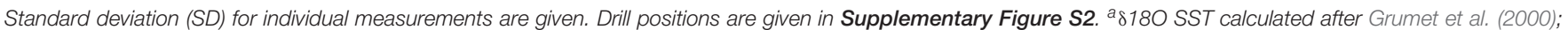

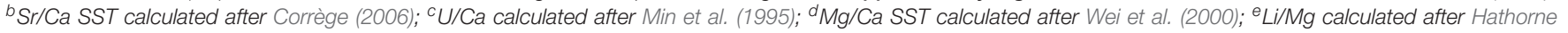
et al. (2013). 
$20-40^{\circ} \mathrm{C}$ and $7.8-9$, respectively, and negatively correlated with the $\left[\mathrm{CO}_{3}{ }^{2-}\right]$ of the precipitating fluid (DeCarlo et al., 2015). At seawater $\left[\mathrm{CO}_{3}{ }^{2-}\right.$ ] of approximately $250 \mu \mathrm{mol} \mathrm{kg}{ }^{-1}$ (Zeebe and Wolf-Gladrow, 2001), the U/Ca of abiogenic aragonite exceeds a value of $4(\mu \mathrm{mol} / \mathrm{mol})$ (DeCarlo et al., 2015), while the U/Ca of the microatolls in this study varied between 1.05 and $1.31(\mu \mathrm{mol} / \mathrm{mol})$. Although the dissolved inorganic carbon (DIC) concentration of the precipitating fluid of the secondary aragonite in our study is unknown, we can speculate that an increased concentration of DIC and $\mathrm{pH}$ contributed to elevated $\left[\mathrm{CO}_{3}{ }^{2-}\right]$. Under this condition, U/Ca would shift toward lower values reaching values $<2$ at $\left[\mathrm{CO}_{3}{ }^{2-}\right]$ starting around 2300 ( $\mu \mathrm{mol} \mathrm{kg}{ }^{-1}$ ) (DeCarlo et al., 2015). As no noticeable difference in U/Ca occurred between bulk samples inside and outside algae bands, we can speculate that the calcifying fluid for the secondary aragonite was high in $\left[\mathrm{CO}_{3}{ }^{2-}\right]$, diminishing the difference of $\mathrm{U} / \mathrm{Ca}$ in biogenic and abiogenic aragonite. The U/Ca of coral skeletons shows strong seasonal variability (Cardinal et al., 2001; Quinn and Sampson, 2002; Felis et al., 2009). For the modern microatolls of the present study, it is impossible to discriminate between natural and diagenetically caused U/Ca variability.

Although variable, mean $\mathrm{Mg} / \mathrm{Ca}$ within algae bands was significant different $(t$-test unpaired, $p$-value $<0.01$ ), yielding lower SSTs than samples outside the bands. The mean value outside the bands $\left(27.8 \pm 1.7^{\circ} \mathrm{C}\right)$ was in accordance with the instrumental record, while corresponding mean SST within the algae bands was $23.1\left( \pm 3.5^{\circ} \mathrm{C}\right)$. Among the proxy approaches used, $\mathrm{Mg} / \mathrm{Ca}$ showed the largest mean temperature difference between samples obtained inside and outside the algae bands. The variability of $\mathrm{Mg} / \mathrm{Ca}$ in coral skeletons for SST is about four times that of Sr/Ca (Mitsuguchi et al., 1996), resulting in a higher sensitivity for temperature reconstructions. Cross and Cross (1983) showed that the Mg concentration decreases during coral diagenesis, while the mechanism remained unconstrained. The bulk and high-resolution analyses of the present study show that $\mathrm{Mg} / \mathrm{Ca}$ was decreased in the secondary aragonite, suggesting that the diagenetic mechanism proposed in the current study might be causative or contributing to the observed diagenetic change in $\mathrm{Mg}$ concentration. Nano-SIMS Mg/Ca maps suggested a maximum decrease in $\mathrm{Mg} / \mathrm{Ca}>50 \%$ in the secondary blocky aragonite cement, yielding unrealistic negative SST excursions. As a result, also small contributions of abiogenic aragonite might lead to a noticeable bias of $\mathrm{Mg} / \mathrm{Ca}-\mathrm{SST}$ in bulk samples. Therefore, $\mathrm{Mg} / \mathrm{Ca}$ variability might serve as a sensitive indicator for the onset of secondary aragonite precipitation during earliest coral marine diagenesis, while other SST proxies are rather insensitive to small contributions of secondary aragonite.

Similar to $\mathrm{Mg} / \mathrm{Ca}$, the $\mathrm{Li} / \mathrm{Mg}$ SST proxy yielded statistically significant deviating values within the studied corals, indicating cooler temperatures (mean $\mathrm{Li} / \mathrm{Mg}_{\mathrm{SST}} 25.1 \pm 2.0^{\circ} \mathrm{C}$ ) within algae bands. According to a recent conceptual model of biomineralization (Marchitto et al., 2018), Li/Mg of the coral precipitating fluid is controlled by a Ca-uptake mechanism strongly discriminating against Li. Due to Rayleigh fractionation during ongoing aragonite precipitation, most $\mathrm{Li}$ and $\mathrm{Mg}$ remain in the calcifying fluid with a $\mathrm{Li} / \mathrm{Mg}$ close to seawater. As a consequence, $\mathrm{Li} / \mathrm{Mg}$ of coral aragonite is rather unbiased by biogenic element partitioning during precipitation. Therefore, it can be assumed that the mean $\mathrm{Li} / \mathrm{Mg}$ increase of the bulk samples from within the algae bands is primarily the result of contributing secondary aragonite and also serves as a sensitive indicator for secondary aragonite formation as a result of earliest diagenesis.

\section{CONCLUSION}

The present study shows evidence that endolithic algae can induce early diagenesis of primary coral aragonite starting almost immediately after skeleton formation. Diagenesis does not only include coral dissolution and generation of secondary porosity, but likely also facilitates the reprecipitation of secondary aragonite within close proximity. In contrast to the biologically controlled formation of the primary skeleton, the secondary aragonite is precipitated under abiotic conditions, leading to characteristic shifts in element ratios. While $\delta^{18} \mathrm{O}, \delta^{13} \mathrm{C}$, and $\mathrm{U} / \mathrm{Ca}$ did not show statistically significant differences between bulk samples from inside and outside algae bands, mean $\mathrm{Sr} / \mathrm{Ca}$ and $\mathrm{Li} / \mathrm{Mg}$ within algae bands were statistically significant higher, while $\mathrm{Mg} / \mathrm{Ca}$ was lower. Among these three element ratios, $\mathrm{Mg} / \mathrm{Ca}$ and $\mathrm{Li} / \mathrm{Mg}$ showed the highest sensitivity toward the contribution of secondary aragonite, which might make them a useful tool to detect early diagenetic secondary carbonate formation within microatolls.

Based on laboratory experiments, we propose a novel precipitation mechanism largely governed by an active $\mathrm{Ca}$ transport within the siphonal thallus of endolithic green algae as O. quekettii from the site of dissolution into the primary coral pore space volume. We also detected the presence of a thin, presumably organic, layer acting as a nucleation template for secondary aragonite.

Coral microatolls might serve as model organisms to study the potential diagenetic impact of endolithic green algae under changing climatic conditions, including ocean warming and acidification.

\section{AUTHOR CONTRIBUTIONS}

SK carried out sample preparation, laboratory experiments, light microscopy, data analysis, and image post-processing and wrote the manuscript with input from all authors. VL obtained the coral samples and contributed to sample preparation and data analysis. GN carried out Raman spectroscopy. TD carried out $\mu \mathrm{CT}$ measurements of coral slabs. SB carried out $\mu \mathrm{CT}$ measurements of coral subsamples. TL provided access and guidance to SEM and contributed to the image acquisition. AV carried out Nano-SIMS measurements. SG provided access and guidance to $\mu \mathrm{CT}$ imaging. AE obtained the coral samples and devised and directed the study.

\section{FUNDING}

This study was funded by the Deutsche Forschungsgemeinschaft FOR 1644 Collaborative Research Initiative CHARON-Phase II. 
The NanoSIMS at the Leibniz Institute for Baltic Sea Research in Warnemuende (IOW) was funded by the German Federal Ministry of Education and Research (BMBF), grant identifier 03F0626A.

\section{ACKNOWLEDGMENTS}

R. Rashid is thanked for his aid during coral sampling. A. Kolevica and R. Surberg are thanked for measuring trace element ratios. S. Fessler is thanked for stable isotope measurements.

\section{REFERENCES}

Abelson, P. H. (1955). Paleobiochemistry: Organic Constituents of Fossils, Carnegie Institution of Washington, Yearbook, No. 54. Washington, DC: Carnegie Institution of Washington 107-109.

Anthony, K. R., Kline, D. I., Diaz-Pulido, G., Dove, S., and Hoegh-Guldberg, O. (2008). Ocean acidification causes bleaching and productivity loss in coral reef builders. Proc. Natl. Acad. Sci. U.S.A. 105, 17442-17446. doi: 10.1073/pnas. 0804478105

Arthurton, R., Brampton, A., Kaaya, C., and Mohamed, S. (1999). Late Quaternary coastal stratigraphy on a platform-fringed tropical coast. a case study from Zanzibar, Tanzania. J. Coast. Res. 15, 635-644.

Bak, R., and Laane, R. (1987). Annual black bands in skeletons of reef corals (Scleractinia). Mar. Ecol. Prog. Ser. 38, 169-175. doi: 10.3354/meps038169

Bar-Matthews, M., Wasserburg, G., and Chen, J. (1993). Diagenesis of fossil coral skeletons. correlation between trace elements, textures, and 234U238U. Geochim. Cosmochim. Acta 57, 257-276. doi: 10.1016/0016-7037(93)90429-z

Barnes, D., and Lough, J. (1993). On the nature and causes of density banding in massive coral skeletons. J. Exp. Mar. Biol. Ecol. 167, 91-108. doi: 10.1016/00220981(93)90186-r

Berner, E. K., and Berner, R. A. (1987). Global Water Cycle: Geochemistry and Environment. Upper Saddle River, NJ: Prentice-Hall.

Boggs, S. Jr. (2014). Principles of Sedimentology and Stratigraphy. London: Pearson Education.

Braissant, O., Cailleau, G., Dupraz, C., and Verrecchia, A. P. (2003). Bacterially induced mineralization of calcium carbonate in terrestrial environments. The role of exopolysaccharides and amino acids. J. Sediment. Res. 73, 485-490. doi: 10.1306/111302730485

Brini, M., Calì, T., Ottolini, D., and Carafoli, E. (2013). Intracellular Calcium Homeostasis and Signaling, Metallomics and the Cell. Berlin: Springer, 119-168.

Buddemeier, R. W., Maragos, J. E., and Knutson, D. W. (1974). Radiographic studies of reef coral exoskeletons. rates and patterns of coral growth. J. Exp. Mar. Biol. Ecol. 14, 179-199. doi: 10.1016/0022-0981(74)90024-0

Buster, N. A., and Holmes, C. W. (2006). Magnesium content within the skeletal architecture of the coral Montastraea faveolata. locations of brucite precipitation and implications to fine-scale data fluctuations. Coral Reefs 25:243. doi: 10.1007/s00338-006-0092-y

Cantin, N. E., Cohen, A. L., Karnauskas, K. B., Tarrant, A. M., and McCorkle, D. C. (2010). Ocean warming slows coral growth in the central Red Sea. Science 329, 322-325. doi: 10.1126/science.1190182

Cardinal, D., Hamelin, B., Bard, E., and Pätzold, J. (2001). Sr/Ca, U/Ca and $\delta 180$ records in recent massive corals from Bermuda: relationships with sea surface temperature. Chem. Geol. 176, 213-233. doi: 10.1016/s0009-2541(00)00396-x

Chalker, B., Barnes, D., and Isdale, P. (1985). Calibration of X-ray densitometry for the measurement of coral skeletal density. Coral Reefs 4, 95-100. doi: 10.1007/ bf00300867

Chappell, J., Omura, A., Esat, T., McCulloch, M., Pandolfi, J., Ota, Y., et al. (1996). Reconciliaion of late Quaternary sea levels derived from coral terraces at Huon Peninsula with deep sea oxygen isotope records. Earth Planet. Sci. Lett. 141, 227-236. doi: $10.1016 / 0012-821 x(96) 00062-3$

Chazottes, V., Le Campion-Alsumard, T., and Peyrot-Clausade, M. (1995). Bioerosion rates on coral reefs. interactions between macroborers, microborers
S. Plewe is thanked for help with SEM imaging. F. Böhm and I. Taubner are thanked for providing coral material for laboratory incubations. N. Glock and H. Jurikova are thanked for their help in formatting and embedding coral specimen.

\section{SUPPLEMENTARY MATERIAL}

The Supplementary Material for this article can be found online at: https://www.frontiersin.org/articles/10.3389/feart. 2019.00304/full\#supplementary-material

and grazers (Moorea, French Polynesia). Palaeogeogr. Palaeoclimatol. Palaeoecol. 113, 189-198. doi: 10.1016/0031-0182(95)00043-1

Chen, S., Gagnon, A. C., and Adkins, J. F. (2018). Carbonic anhydrase, coral calcification and a new model of stable isotope vital effects. Geochim. Cosmochim. Acta 236, 179-197. doi: 10.1016/j.gca.2018. 02.032

Corrège, T. (2006). Sea surface temperature and salinity reconstruction from coral geochemical tracers. Palaeogeogr. Palaeoclimatol. Palaeoecol. 232, 408-428. doi: 10.1016/j.palaeo.2005.10.014

Cross, T. S., and Cross, B. W. (1983). U, Sr, and $\mathrm{Mg}$ in Holocene and Pleistocene corals A. palmata and M. annularis. J. Sediment. Res. 53, 587-594.

Dana, J. (1849). Geological observations on Oregon and northern California. US Explor. Exped., 1838-42, under the command of Charles Wilkes. Geology 10, 611-678.

Davies, P. J., and Hutchings, P. A. (1983). Initial colonization, erosion and accretion of coral substrate. Coral Reefs 2, 27-35. doi: 10.1007/bf00304729

De Villiers, S. (1999). Seawater strontium and Sr/Ca variability in the Atlantic and Pacific oceans. Earth Planet. Sci. Lett. 171, 623-634. doi: 10.1016/s0012$821 x(99) 00174-0$

DeCarlo, T. M., Gaetani, G. A., Holcomb, M., and Cohen, A. L. (2015). Experimental determination of factors controlling $\mathrm{U} / \mathrm{Ca}$ of aragonite precipitated from seawater. Implications for interpreting coral skeleton. Geochim. Cosmochim. Acta 162, 151-165. doi: 10.1016/j.gca.2015. 04.016

Degens, E. T. (2012). Perspectives on Biogeochemistry. Berlin: Springer Science \& Business Media.

Dietzel, M., Gussone, N., and Eisenhauer, A. (2004). Co-precipitation of Sr2+ and $\mathrm{Ba} 2+$ with aragonite by membrane diffusion of $\mathrm{CO} 2$ between 10 and $50 \mathrm{C}$. Chem. Geol. 203, 139-151. doi: 10.1016/j.chemgeo.2003.09.008

DiSalvo, L. H. (1969). Isolation of bacteria from the corallum of Porites lobata (Vaughn) and its possible significance. Am. Zool. 9, 735-740. doi: 10.1093/icb/ 9.3.735

Dominguez, D. C. (2004). Calcium signalling in bacteria. Mol. Microbiol. 54, 291-297. doi: 10.1111/j.1365-2958.2004.04276.x

Duerden, J. E. (1902). Boring algae as agents in the disintegration of corals. Bull. AMNH 16:25.

Enmar, R., Stein, M., Bar-Matthews, M., Sass, E., Katz, A., and Lazar, B. (2000). Diagenesis in live corals from the Gulf of Aqaba. I: effect on paleo-oceanography tracers. Geochim. Cosmochim. Acta 64, 3123-3132. doi: 10.1016/s0016-7037(00) 00417-8

Farley, N., Samankassou, E., Antonioli, G., Hallmann, N., Camoin, G., Eisenhauer, A., et al. (2018). "Assessment of paleothermometry using coral microatolls. record from Bora Bora, French Polynesia," in Proceedings of the EGU General Assembly Conference Abstracts, Vol. 20, Vienna, 10486.

Felis, T., Suzuki, A., Kuhnert, H., Dima, M., Lohmann, G., and Kawahata, H. (2009). Subtropical coral reveals abrupt early-twentieth-century freshening in the western North Pacific Ocean. Geology 37, 527-530. doi: 10.1130/g2 5581a.1

Fine, M., and Loya, Y. (2002). Endolithic algae. an alternative source of photoassimilates during coral bleaching. Proc. R. Soc. Lond. Ser. B Biol. Sci. 269, 1205-1210. doi: 10.1098/rspb.2002.1983 
Fine, M., Meroz-Fine, E., and Hoegh-Guldberg, O. (2005). Tolerance of endolithic algae to elevated temperature and light in the coral Montipora monasteriata from the southern Great Barrier Reef. J. Exp. Biol. 208, 75-81. doi: 10.1242/jeb. 01381

Försterra, G., and Häussermann, V. (2008). Unusual symbiotic relationships between microendolithic phototrophic organisms and azooxanthellate coldwater corals from Chilean fjords. Mar. Ecol. Prog. Ser. 370, 121-125. doi: 10. 3354/meps07630

Garcia-Pichel, F., Ramírez-Reinat, E., and Gao, Q. (2010). Microbial excavation of solid carbonates powered by P-type ATPase-mediated transcellular Ca2+ transport. Proc. Natl. Acad. Sci. U.S.A. 107, 21749-21754. doi: 10.1073/pnas. 1011884108

Glynn, P. W., Colley, S. B., Eakin, C. M., Smith, D., Cortés, J., Gassman, N., et al. (1994). Reef coral reproduction in the eastern Pacific. Costa Rica, Panamá, and Galápagos Islands (Ecuador). II. Poritidae. Mar. Biol. 118, 191-208. doi: 10.1007/bf00349785

Grange, J., Rybarczyk, H., and Tribollet, A. (2015). The three steps of the carbonate biogenic dissolution process by microborers in coral reefs (New Caledonia). Environ. Sci. Pollut. Res. 22, 13625-13637. doi: 10.1007/s11356-014-4069-z

Griffiths, N., Müller, W., Johnson, K. G., and Aguilera, O. A. (2013). Evaluation of the effect of diagenetic cements on element/Ca ratios in aragonitic Early Miocene ( $16 \mathrm{Ma}$ ) Caribbean corals. Implications for 'deep-time'palaeoenvironmental reconstructions. Palaeogeogr. Palaeoclimatol. Palaeoecol. 369, 185-200. doi: 10.1016/j.palaeo.2012.10.018

Grottoli, A. (1999). Variability of stable isotopes and maximum linear extension in reef-coral skeletons at Kaneohe Bay. Hawaii. Mar. Biol. 135, 437-449. doi: $10.1007 / \mathrm{s} 002270050644$

Grumet, N., Dunbar, R., and Cole, J. (2000). "Multisite record of climate change from Indian Ocean corals," in Proceedings of the 9th International Coral Reef Symposium, Indonesia, 359-364.

Gupta, L. P., Suzuki, A., and Kawahata, H. (2007). Endolithic aspartic acid as a proxy of fluctuations in coral growth. J. Geophys. Res. Biogeosci. 112:G01001.

Halldal, P. (1968). Photosynthetic capacities and photosynthetic action spectra of endozoic algae of the massive coral Favia. Biol. Bull. 134, 411-424. doi: $10.2307 / 1539860$

Hartmann, A., Carilli, J., Norris, R., Charles, C., and Deheyn, D. (2010). Stable isotopic records of bleaching and endolithic algae blooms in the skeleton of the boulder forming coral Montastraea faveolata. Coral Reefs 29, 1079-1089. doi: 10.1007/s00338-010-0667-5

Hathorne, E. C., Felis, T., Suzuki, A., Kawahata, H., and Cabioch, G. (2013). Lithium in the aragonite skeletons of massive Porites corals. A new tool to reconstruct tropical sea surface temperatures. Paleoceanography 28, 143-152. doi: 10.1029/2012pa002311

Henderson, G., Cohen, A., and O'nions, R. (1993). 234U/238U ratios and230Th ages for Hateruma Atoll corals. implications for coral diagenesis and seawater234U/238U ratios. Earth Planet. Sci. Lett. 115, 65-73. doi: 10.1016/ 0012-821x(93)90213-s

Hendy, E., Gagan, M., Lough, J., McCulloch, M., and DeMenocal, P. (2007). Impact of skeletal dissolution and secondary aragonite on trace element and isotopic climate proxies in Porites corals. Paleoceanography 22, 1-10.

Highsmith, R. C. (1981). Lime-boring algae in hermatypic coral skeletons. J. Exp. Mar. Biol. Ecol. 55, 267-281. doi: 10.1016/0022-0981(81)90117-9

Hoegh-Guldberg, O. (1999). Climate change, coral bleaching and the future of the world's coral reefs. Mar. Freshw. Res. 50, 839-866.

Ingalls, A. E., Lee, C., and Druffel, E. R. (2003). Preservation of organic matter in mound-forming coral skeletons. Geochim. Cosmochim. Acta 67, 2827-2841. doi: 10.1016/s0016-7037(03)00079-6

Isdale, P. (1984). Fluorescent bands in massive corals record centuries of coastal rainfall. Nature 310:578. doi: 10.1038/310578a0

Jarosewich, E., and MacIntyre, I. G. (1983). Carbonate reference samples for electron microprobe and scanning electron microscope analyses. J. Sediment. Res. 53, 677-678. doi: 10.1306/212f828d-2b24-11d7-8648000102c1865d

Jarosewich, E., Nelen, J., and Norberg, J. A. (1980). Reference samples for electron microprobe analysis. Geostand. Newslett. 4, 43-47. doi: 10.1111/j.1751-908x. 1980.tb00273.x

Jarosewich, E., and White, J. S. (1987). Strontianite reference sample for electron microprobe and SEM analyses. J. Sediment. Res. 57, 762-763. doi: 10.1306/ 212f8c10-2b24-11d7-8648000102c1865d
Jeffrey, S. (1968). Pigment composition of Siphonales algae in the brain coral Favia. Biol. Bull. 135, 141-148. doi: 10.2307/1539621

Jones, O. A. (2012). Biology and Geology of Coral Reefs V1. Geology 1. Amsterdam: Elsevier.

Jørgensen, B. B. (1977). The sulfur cycle of a coastal marine sediment (Limfjorden. Denmark). Limnol. Oceanogr. 22, 814-832. doi: 10.4319/lo.1977.22. 5.0814

Kinsman, D. J., and Holland, H. D. (1969). The co-precipitation of cations with $\mathrm{CaCO} 3-\mathrm{IV}$. The co-precipitation of $\mathrm{Sr} 2+$ with aragonite between $16^{\circ}$ and $96^{\circ}$ C. Geochim. Cosmochim. Acta 33, 1-17. doi: 10.1016/0016-7037(69)90 089-1

Knutson, D. W., Buddemeier, R. W., and Smith, S. V. (1972). Coral chronometers. seasonal growth bands in reef corals. Science 177, 270-272. doi: 10.1126/science. 177.4045.270

Kontoyannis, C. G., and Vagenas, N. V. (2000). Calcium carbonate phase analysis using XRD and FT-Raman spectroscopy. Analyst 125, 251-255. doi: 10.1039/ a908609i

Kornmann, P., and Sahling, P.-H. (1980). Ostreobium quekettii (Codiales, Chlorophyta). Helgoländer Meeresuntersuchungen 34:115. doi: 10.1007/ bf01984034

Krause, S., Liebetrau, V., Gorb, S., Sanchez-Roman, M., McKenzie, J. A., and Treude, T. (2012). Microbial nucleation of Mg-rich dolomite in exopolymeric substances under anoxic modern seawater salinity. New insight into an old enigma. Geology 40, 587-590. doi: 10.1130/g32923.1

La Verde, V., Dominici, P., and Astegno, A. (2018). Towards understanding plant calcium signaling through calmodulin-like proteins. A biochemical and structural perspective. Int. J. Mol. Sci. 19:1331. doi: 10.3390/ijms19051331

LaJeunesse, T. C., Pettay, D. T., Sampayo, E. M., Phongsuwan, N., Brown, B., Obura, D. O., et al. (2010). Long-standing environmental conditions, geographic isolation and host-symbiont specificity influence the relative ecological dominance and genetic diversification of coral endosymbionts in the genus symbiodinium. J. Biogeogr. 37, 785-800. doi: 10.1111/j.1365-2699.2010. 02273.x

Le Campion-Alsumard, T., Golubic, S., and Hutchings, P. (1995). Microbial endoliths in skeletons of live and dead corals. Porites lobata (Moorea, French Polynesia). Oceanogr. Lit. Rev. 9:781.

Lewis, S. E., Wüst, R. A., Webster, J. M., and Shields, G. A. (2008). Mid-late Holocene sea-level variability in eastern Australia. Terra Nova 20, 74-81. doi: 10.1111/j.1365-3121.2007.00789.x

Lough, J., Barnes, D., Devereux, M., Tobin, B., and Tobin, S. (1999). Variability in growth characteristics of massive Porites on the Great Barrier Reef. CRC Reef Research Centre Technical Report, Vol. 28. Townsville Volume: CRC Reef Research Centre, 95.

Maberly, S., Raven, J., and Johnston, A. (1992). Discrimination between 12 C and 13 C by marine plants. Oecologia 91, 481-492. doi: 10.1007/bf00650320

Macintyre, I. G., and Towe, K. M. (1976). Skeletal calcite in living scleractinian corals. microboring fillings, not primary skeletal deposits. Science 193, 701-702. doi: 10.1126/science.193.4254.701

Maier, C., Weinbauer, M., and Pätzold, J. (2010). Stable isotopes reveal limitations in $\mathrm{C}$ and $\mathrm{N}$ assimilation in the Caribbean reef corals Madracis auretenra, M. carmabi and M. formosa. Mar. Ecol. Prog. Ser. 412, 103-112. doi: 10.3354/ meps08674

Marcelino, V. R., and Verbruggen, H. (2016). Multi-marker metabarcoding of coral skeletons reveals a rich microbiome and diverse evolutionary origins of endolithic algae. Sci. Rep. 6:31508.

Marchitto, T., Bryan, S., Doss, W., McCulloch, M., and Montagna, P. (2018). A simple biomineralization model to explain $\mathrm{Li}, \mathrm{Mg}$, and $\mathrm{Sr}$ incorporation into aragonitic foraminifera and corals. Earth Planet. Sci. Lett. 481, 20-29. doi: 10.1016/j.epsl.2017.10.022

Marion, G., Millero, F. J., and Feistel, R. (2009). Precipitation of solid phase calcium carbonates and their effect on application of seawater S A-T-P models. Ocean Sci. 5, 285-291. doi: 10.5194/os-5-285-2009

Massé, A., Domart-Coulon, I., Golubic, S., Duché, D., and Tribollet, A. (2018). Early skeletal colonization of the coral holobiont by the microboring Ulvophyceae Ostreobium sp. Sci. Rep. 8:2293.

McClanahan, T. R., Ateweberhan, M., Muhando, C. A., Maina, J., and Mohammed, M. S. (2007). Effects of climate and seawater temperature variation on coral bleaching and mortality. Ecol. Monogr. 77, 503-525. doi: 10.1890/06-1182.1 
McGregor, H. V., Woodroffe, C., Fischer, M., Gagan, M., and Fink, D. (2013). Coral microatoll reconstructions of El Niño-Southern Oscillation. N. Windows Season. Interann. Process. 21, 52-53. doi: 10.22498/pages.21.2.52

Min, G. R., Edwards, R. L., Taylor, F. W., Recy, J., Gallup, C. D., and Beck, J. W. (1995). Annual cycles of UCa in coral skeletons and UCa thermometry. Geochim. Cosmochim. Acta 59, 2025-2042.

Mitsuguchi, T., Matsumoto, E., Abe, O., Uchida, T., and Isdale, P. J. (1996). Mg/Ca thermometry in coral skeletons. Science 274, 961-963. doi: 10.1126/science.274. 5289.961

Nehrke, G., and Nouet, J. (2011). Confocal Raman microscope mapping as a tool to describe different mineral and organic phases at high spatial resolution within marine biogenic carbonates. case study on Nerita undata (Gastropoda, Neritopsina). Biogeosciences 8, 3761-3769. doi: 10.5194/bg-8-3761-2011

Nothdurft, L. D., and Webb, G. E. (2009). Earliest diagenesis in scleractinian coral skeletons. implications for palaeoclimate-sensitive geochemical archives. Facies 55, 161-201. doi: 10.1007/s10347-008-0167-z

Obert, J. C., Scholz, D., Felis, T., Lippold, J., Jochum, K. P., and Andreae, M. O. (2019). Improved constraints on open-system processes in fossil reef corals by combined $\mathrm{Th} / \mathrm{U}, \mathrm{Pa} / \mathrm{U}$ and $\mathrm{Ra} / \mathrm{Th}$ dating. A case study from Aqaba, Jordan. Geochim. Cosmochim. Acta 245, 459-478. doi: 10.1016/j.gca.2018.11.024

Pereira, N. S., Sial, A. N., Kikuchi, R. K., Ferreira, V. P., Ullmann, C. V., Frei, R., et al. (2015). Coral-based climate records from tropical South Atlantic. 2009/2010 ENSO event in C and O isotopes from Porites corals (Rocas Atoll, Brazil). Anais da Academia Brasileira de Ciências 87, 1939-1957. doi: 10.1590/ 0001-3765201520150072

Perrin, C., and Smith, D. C. (2007). Earliest steps of diagenesis in living scleractinian corals. evidence from ultrastructural pattern and Raman spectroscopy. J. Sediment. Res. 77, 495-507. doi: 10.2110/jsr.2007.051

Perry, C., Edinger, E., Kench, P., Murphy, G., Smithers, S., Steneck, R., et al. (2012). Estimating rates of biologically driven coral reef framework production and erosion. a new census-based carbonate budget methodology and applications to the reefs of Bonaire. Coral Reefs 31, 853-868. doi: 10.1007/s00338-012-0901-4

Polerecky, L., Adam, B., Milucka, J., Musat, N., Vagner, T., and Kuypers, M. M. (2012). Look@ NanoSIMS-a tool for the analysis of nanoSIMS data in environmental microbiology. Environ. Microbiol. 14, 1009-1023. doi: 10.1111/ j.1462-2920.2011.02681.x

Przeslawski, R., Ahyong, S., Byrne, M., Woerheide, G., and Hutchings, P. (2008). Beyond corals and fish. the effects of climate change on noncoral benthic invertebrates of tropical reefs. Glob. Change Biol. 14, 2773-2795. doi: 10.1111/j. 1365-2486.2008.01693.x

Quinn, T. M., and Sampson, D. E. (2002). A multiproxy approach to reconstructing sea surface conditions using coral skeleton geochemistry. Paleoceanogr. Paleoclimatol. 17, 14-11.

Quinn, T. M., and Taylor, F. W. (2006). SST artifacts in coral proxy records produced by early marine diagenesis in a modern coral from Rabaul. Papua New Guinea. Geophys. Res. Lett. 33:L04601.

Ralph, P. J., Larkum, A. W., and Kühl, M. (2007). Photobiology of endolithic microorganisms in living coral skeletons. 1. Pigmentation, spectral reflectance and variable chlorophyll fluorescence analysis of endoliths in the massive corals Cyphastrea serailia, Porites lutea and Goniastrea australensis. Mar. Biol. 152, 395-404. doi: 10.1007/s00227-007-0694-0

Reay, A., Johnstone, R., and Kawachi, Y. (1993). Anorthoclase, a second microprobe standard from Kakanui. New Zealand. Geostand. Newslett. 17, 135-136. doi: 10.1111/j.1751-908x.1993.tb00129.x

Remusat, L., Hatton, P.-J., Nico, P. S., Zeller, B., Kleber, M., and Derrien, D. (2012). NanoSIMS study of organic matter associated with soil aggregates. advantages, limitations, and combination with STXM. Environ. Sci. Technol. 46, 3943-3949. doi: $10.1021 /$ es203745k

Revelle, R., and Emery, K. O. (1957). Chemical Erosion of Beach Rock and Exposed Reef Rock. Bikini and Nearby Atolls. Marshall Islands: US Government Printing Office, 930.

Ribaud-Laurenti, A., Hamelin, B., Montaggioni, L., and Cardinal, D. (2001). Diagenesis and its impact on $\mathrm{Sr} / \mathrm{Ca}$ ratio in Holocene Acropora corals. Int. J. Earth Sci. 90, 438-451. doi: 10.1007/s005310000168

Roche, R. C., Perry, C. T., Smithers, S. G., Leng, M. J., Grove, C. A., Sloane, H. J., et al. (2014). Mid-Holocene sea surface conditions and riverine influence on the inshore Great Barrier Reef. Holocene 24, 885-897. doi: 10.1177/ 0959683614534739
Rosenberg, E., Koren, O., Reshef, L., Efrony, R., and Zilber-Rosenberg, I. (2007). The role of microorganisms in coral health, disease and evolution. Nat. Rev. Microbiol. 5:355. doi: 10.1038/nrmicro1635

Saka, S. K., Vogts, A., Kröhnert, K., Hillion, F., Rizzoli, S. O., and Wessels, J. T. (2014). Correlated optical and isotopic nanoscopy. Nat. Commun. 5:3664.

Sayani, H. R., Cobb, K. M., Cohen, A. L., Elliott, W. C., Nurhati, I. S., Dunbar, R. B., et al. (2011). Effects of diagenesis on paleoclimate reconstructions from modern and young fossil corals. Geochim. Cosmochim. Acta 75, 6361-6373. doi: 10.1016/j.gca.2011.08.026

Schlichter, D., Kampmann, H., and Conrady, S. (1997). Trophic potential and photoecology of endolithic algae living within coral skeletons. Mar. Ecol. 18, 299-317. doi: 10.1111/j.1439-0485.1997.tb00444.x

Schlichter, D., Zscharnack, B., and Krisch, H. (1995). Transfer of photoassimilates from endolithic algae to coral tissue. Naturwissenschaften 82, 561-564. doi: $10.1007 / \mathrm{s} 001140050234$

Schoepf, V., Stat, M., Falter, J. L., and McCulloch, M. T. (2015). Limits to the thermal tolerance of corals adapted to a highly fluctuating, naturally extreme temperature environment. Sci. Rep. 5:17639.

Scoffin, T. P., and Stoddart, D. (1978). The nature and significance of microatolls. Philos. Trans. R. Soc. Lond. B Biol. Sci. 284, 99-122. doi: 10.1098/rstb.197 8.0055

Shashar, N., and Stambler, N. (1992). Endolithic algae within corals-life in an extreme environment. J. Exp. Mar. Biol. Ecol. 163, 277-286. doi: 10.1016/00220981(92)90055-f

Smith, R. (1995). Calcium and bacteria. Adv. Microb. Physiol. 37, 83-133.

Stanley, G. D. Jr. (2003). The evolution of modern corals and their early history. Earth Sci. Rev. 60, 195-225. doi: 10.1016/s0012-8252(02)00104-6

Stoddart, D. R., and Scoffin, T. P. (1979). Microatolls. review of form, origin and terminology. Atoll Res. Bull. 224, 1-17. doi: 10.5479/si.00775630.224.1

Titlyanov, E. A., Titlyanova, T. V., and Chapman, D. J. (2008). Dynamics and patterns of algal colonization on mechanically damaged and dead colonies of the coral Porites lutea. Botanica Mar. 51, 285-296.

Tribble, G. W., Sansone, F. J., and Smith, S. V. (1990). Stoichiometric modeling of carbon diagenesis within a coral reef framework. Geochim. Cosmochim. Acta 54, 2439-2449. doi: 10.1016/0016-7037(90)90231-9

Tribollet, A. (2008). Dissolution of dead corals by euendolithic microorganisms across the northern Great Barrier Reef (Australia). Microb. Ecol. 55, 569-580. doi: 10.1007/s00248-007-9302-6

Tribollet, A., Godinot, C., Atkinson, M., and Langdon, C. (2009). Effects of elevated pCO2 on dissolution of coral carbonates by microbial euendoliths. Glob. Biogeochem. Cycles 23:GB3008.1-7.

Tribollet, A., and Golubic, S. (2011). Reef Bioerosion. Agents and Processes, Coral reefs. An Ecosystem in Transition. Berlin: Springer, 435-449.

Verbruggen, H., and Tribollet, A. (2011). Boring algae. Curr. Biol. 21, R876-R877.

Veron, J. E. N. (2000), Corals of the World. Australian Institute of Marine Science: Townsville, QLD.

Waite, A. J., and Swart, P. K. (2015). The inversion of aragonite to calcite during the sampling of skeletal archives. Implications for proxy interpretation. Rapid Commun. Mass Spectrom. 29, 955-964. doi: 10.1002/rcm.7180

Weber, J. N., White, E. W., and Weber, P. H. (1975). Correlation of density banding in reef coral skeletons with environmental parameters. the basis for interpretation of chronological records preserved in the coralla of corals. Paleobiology 1, 137-149. doi: 10.1017/s0094837300002335

Wei, G., Sun, M., Li, X., and Nie, B. (2000). Mg/Ca, Sr/Ca and U/Ca ratios of a porites coral from Sanya Bay, Hainan Island, South China Sea and their relationships to sea surface temperature. Palaeogeogr. Palaeoclimatol. Palaeoecol. 162, 59-74. doi: 10.1016/s0031-0182(00)00105- х

White, P. J., and Broadley, M. R. (2003). Calcium in plants. Ann. Bot. 92, 487-511. Wizemann, A., Nandini, S. D., Stuhldreier, I., Sánchez-Noguera, C., Wisshak, M., Westphal, H., et al. (2018). Rapid bioerosion in a tropical upwelling coral reef. PLoS One 13:e0202887. doi: 10.1371/journal.pone.020 2887

Woodroffe, C., and McLean, R. (1990). Microatolls and recent sea level change on coral atolls. Nature 344, 531-534. doi: 10.1038/344531a0

Wu, H. C., Linsley, B. K., Dassié, E. P., Schiraldi, B., and deMenocal, P. B. (2013). Oceanographic variability in the South Pacific Convergence Zone region over the last 210 years from multi-site coral Sr/Ca records. Geochem. Geophys. Geosyst. 14, 1435-1453. doi: 10.1029/2012gc004293 
Yamazaki, S., Nakamura, T., Yuen, Y., and Yamasaki, H. (2008). "Reef-building coral Goniastrea aspera harbour a novel filamentous cyanobacterium in their skeleton," in Proceedings of the 11th International Coral Reef Symposium, Lauderdale, FL, 265-268.

Zeebe, R. E., and Wolf-Gladrow, D. (2001). CO2 in Seawater. Equilibrium, Kinetics, Isotopes. Equilibrium, Kinetics, Isotopes. Amsterdam: Elsevier.

Zubia, M., and Peyrot-Clausade, M. (2001). Internal bioerosion of Acropora formosa in Réunion (Indian Ocean). microborer and macroborer activities. Oceanol. Acta 24, 251-262. doi: 10.1016/s0399-1784(01)01144-6

Zumft, W. G. (1997). Cell biology and molecular basis of denitrification. Microbiol. Mol. Biol. Rev. 61, 533-616.
Conflict of Interest: The authors declare that the research was conducted in the absence of any commercial or financial relationships that could be construed as a potential conflict of interest.

Copyright (c) 2019 Krause, Liebetrau, Nehrke, Damm, Büsse, Leipe, Vogts, Gorb and Eisenhauer. This is an open-access article distributed under the terms of the Creative Commons Attribution License (CC BY). The use, distribution or reproduction in other forums is permitted, provided the original author(s) and the copyright owner(s) are credited and that the original publication in this journal is cited, in accordance with accepted academic practice. No use, distribution or reproduction is permitted which does not comply with these terms. 